\title{
1 Agrochemicals disrupt multiple endocrine axes in 2 amphibians
}

Trudeau VL (1)*, Thomson P (2), Zhang WS (1), Reyaud S (3), Navarro-Martin L (4) and VS Langlois (2)

\section{Affiliations:}

(1) Department of Biology, University of Ottawa, 30 Marie Curie Private, Ottawa, ON, Canada, K1N 6N5

(2) Institut national de la recherche scientifique (INRS), Centre Eau Terre Environnement, 490 de la Couronne, Québec (Québec), Canada, G1K 9A9

(3) Laboratoire d'Ecologie Alpine, UMR UGA-USMB-CNRS 5553, Université Grenoble Alpes, CS 40700, 38058 Grenoble cedex 9, France

(4) Institute of Environmental Assessment and Water Research, IDAEA-CSIC, Jordi Girona 18, 08034 Barcelona, Spain

\section{Email contact:}

Vance L. Trudeau (vance.trudeau@uottawa.ca)

Paisley Thomson (paisley.thomson@ete.inrs.ca)

Wo Su Zhang (szhan165@uottawa.ca)

Stéphane Reynaud (stephane.reynaud@univ-grenoble-alpes.fr)

Laia Navarro-Martin (laianavarromartin@gmail.com)

Valérie S. Langlois (Valerie.Langlois@inrs.ca)

\section{${ }^{*}$ Corresponding author:}

Vance L. Trudeau, Professor

University Chair in Neuroendocrinology

University of Ottawa

30 Marie Curie Private

Ottawa, ON, Canada, K1N 6N5

vance.trudeau@uottawa.ca 
Abstract

36 Concern over global amphibian declines and possible links to agrochemical use has led

37 to research on the endocrine disrupting actions of agrochemicals, such as fertilizers,

38 fungicides, insecticides, acaricides, herbicides, metals, and mixtures. Amphibians, like

39 other species, have to partition resources for body maintenance, growth, and

40 reproduction. Recent studies suggest that metabolic impairments induced by endocrine

41 disrupting chemicals, and more particularly agrichemicals, may disrupt physiological

42 constraints associated with these limited resources and could cause deleterious effects

43 on growth and reproduction. Metabolic disruption has hardly been considered for

44 amphibian species following agrichemical exposure. As for metamorphosis, the key

45 thyroid hormone-dependent developmental phase for amphibians, it can either be

46 advanced or delayed by agrichemicals with consequences for juvenile and adult health

47 and survival. While numerous agrichemicals affect anuran sexual development,

48 including sex reversal and intersex in several species, little is known about the

49 mechanisms involved in dysregulation of the sex differentiation processes. Adult

50 anurans display stereotypical male mating calls and female phonotaxis responses

51 leading to successful amplexus and spawning. These are hormone-dependent

52 behaviours at the foundation of reproductive success. Therefore, male vocalizations are

53 highly ecologically-relevant and may be a non-invasive low-cost method for the

54 assessment of endocrine disruption at the population level. While it is clear that

55 agrichemicals disrupt multiple endocrine systems in frogs, very little has been

56 uncovered regarding the molecular and cellular mechanisms at the basis of these

57 actions. This is surprising, given the importance of the frog models to our deep 
58 understanding of developmental biology and thyroid hormone action to understand

59 human health. Several agrichemicals were found to have multiple endocrine effects at

60 once (e.g., targeting both the thyroid and gonadal axes); therefore, the assessment of

61 agrichemicals that alter cross-talk between hormonal systems must be further

62 addressed. Given the diversity of life-history traits in Anura, Caudata, and the

63 Gymnophiona, it is essential that studies on endocrine disruption expand to include the

64 lesser known taxa. Research under ecologically-relevant conditions will also be

65 paramount. Closer collaboration between molecular and cellular endocrinologists and

66 ecotoxicologists and ecologists is thus recommended.

\section{Introduction}

There are countless benefits to intensive agricultural practices, including high

70 productivity, labour concentration, and efficiencies, and thus, major health and

71 economic benefits to people. Loss of natural habitat due to agricultural development is

72 one important contribution to global amphibian declines. This is accompanied by the

73 use of a range of agrochemicals for crop and farm animal management. There is

74 accumulating and controversial evidence that some are endocrine disrupting chemicals

75 (EDCs), or have the potential to disrupt other key physiological control processes that

76 may contribute to reduced amphibian health and significant population declines. The

77 most obvious agrochemicals are the various herbicides, insecticides, fungicides, and

78 fertilizers used (Table 1). However, animal growth promoters, manure and sewage run-

79 off, natural and synthetic steroids, pharmaceuticals and metals can also be considered 
80 as agrochemical pollutants as they are used and measured near-by agricultural

81 activities.

\section{TABLE 1 NEAR HERE}

6,500 species), Caudata (newts and salamanders, $\sim 680$ species), and the

87 Gymnophiona (caecilians, 205 species). Of these, most research on basic endocrine

88 control of development and reproduction, as well as the processes underlying endocrine

89 disruption are largely undertaken with a few anuran species. For the most part, we limit

90 the scope of this review to frogs and toads because data are missing in the other

91 groups. Amphibians appear to be particularly susceptible to disruption of development,

92 because metamorphosis is dependent on the thyroid hormones (THs), and that THs and

93 their receptors are often altered by environmental contaminants. Moreover, sexual

94 development is highly plastic and sex reversal is relatively easy to induce with

95 exogenous sex steroid treatments, among others. Crosstalk between the thyroid,

96 metabolic, and gonadal axes gives rise to additional processes that can be affected by

97 EDCs. Given that tadpole and adult amphibian skin is permeable, many species can

98 take up and respond to pollutants at both life-history stages.

99 Our main objective was to critically review amphibian data on the disruption of

100 metamorphosis, growth, metabolism, and aspects of sexual differentiation and

101 behaviour by agrochemicals. Information on the molecular and cellular mechanisms of

102 action of a given agrochemical may be available, but more often it is not. In this 
103 instance, we review the effects of model endocrine disruptors when there is a paucity of

104 information on agrochemicals. The second objective was to identify areas requiring

105 collaborative research concerning disruption of the hypothalamic-pituitary-thyroid (HPT)

106 axis and the hypothalamic-pituitary-gonad (HPG) axis, and the resultant impacts on

107 amphibian population health.

\section{Metamorphosis and disruption of the hypothalamic-pituitary-thyroid axis}

The HPT axis (Figure 1) is critically important in regulating amphibian

110 development, metamorphosis, and physiology and has been reviewed extensively

111 (Denver et al., 2002; Shi, 2000; Denver, 2009; 2013). The action of THs, thyroxine (T4)

112 and triiodothyronine (T3), are mediated through the TH receptors (TR $\alpha$ and TR $\beta$ )

113 (Yaoita and Brown, 1990; Eliceiri and Brown, 1994). The TRs are liganded transcription

114 factors that dimerize with the retinoic acid receptor (RXR) to induce tissue-specific

115 actions by binding to thyroid response elements (TREs) in promoter regions of $\mathrm{TH}$ -

116 responsive genes, thus, controlling most aspects of the metamorphic progression

117 (Helbing and Atkinson, 1994; Shi, 2000; Buchholz et al., 2004, 2005, 2017).

118 The control of the synthesis, secretion, and metabolism of THs has been described for 119 anurans in several elegant reviews and will not be covered in detail here (Denver et al.,

120 2002; Buchholz et al., 2006; Denver, 2013). Briefly, metamorphic progression is

121 accompanied by a gradual increase in THs and developmental- and tissue-dependent

122 expression patterns of the TRs and deiodinase enzymes. In particular, the type 2

123 deiodinase (DIO2) is required for local conversion of T4 to the more active T3, and

124 metabolism of these to less active forms by type 3 deiodinase (DIO3). Contaminants

125 have the potential to cause adverse effects through interference at many levels: 
126 synthesis of THs (sodium iodide symporter (NIS), thyroid peroxidase (TPO), thyroid

127 stimulating hormone (TSH), thyroid stimulating hormone receptor (TSHR)), plasma

128 transport proteins, cellular uptake mechanisms, TRs, and TH metabolism (e.g.,

129 deiodinase enzymes). Interference with feedback loops and hormonal crosstalk

130 represent other potential mechanisms of endocrine disruption. Several agricultural

131 contaminants have been identified as disruptors of the HPT axis in vertebrates

132 (Leemans et al., 2019). Because TH-signaling is highly conserved across vertebrate

133 species, and anuran metamorphosis is TH-dependent (Heimeier and Shi, 2010),

134 amphibians represent ideal animal models to assess endocrine disruption.

135 Contaminants that affect TH-dependent processes have been associated with

136 alterations in the rate of metamorphosis (Heimeier and Shi, 2010; Miyata and Ose,

137 2012). On the cellular and molecular levels, thyroid gland histology or disruption of the

138 actions of exogenous THs or TH-dependent processes are parameters frequently

139 studied to assess thyroid disruption. Studies on pituitary TSH and the direct

140 measurement of T4, T3 and metabolites in anurans are lacking in general and more

141 specifically as related to endocrine disruption. Measuring and interpreting circulating

142 hormone levels, particularly in small tadpoles, presents a significant technical challenge.

143 Therefore, many studies have used highly sensitive molecular endpoints, such as gene

144 expression of $\mathrm{TH}$-responsive genes, to examine the effects of agrochemicals on the

145 HPT of amphibians (Crump et al., 2002; Lancôt et al., 2013; Navarro-Martín et al.,

146 2014).

148 FIGURE 1 NEAR HERE 
Relevant here is that the developmentally changing levels of T4 and T3, along

150

151

152

153

154

155

156 157 amphibians.
159

160

with tissue-dependent developmental variations in the TRs in anurans drive

metamorphosis. Tadpoles are an excellent model system to unravel the complexities of disruption of hormone-dependent developmental processes. Variations in hormone levels superimposed on changing TRs may lead to major differences in sensitivity and response to a given agrochemical (Rosenfeld et al., 2017). Therefore, it is essential that effects be tested at different developmental stages. While this is far from clear, we provide examples of numerous agrochemicals that impact TH-dependent processes in

\subsection{Fertilizers and Metals}

\subsubsection{Fertilizers}

Nitrogenous fertilizers are commonly applied in agricultural operations and are present in agricultural runoff (Lawniczak et al., 2016). Nitrate and nitrite have been shown to affect the HPT axis in several vertebrate species (Edwards et al., 2006) by competing with uptake of iodide by the thyroid gland, thereby inhibiting TH synthesis (Tonacchera et al., 2004; De Groef et al., 2006; Ward et al., 2010). Therefore, nitrogenous fertilizers represent a class of agrochemicals that may potentially interfere with the HPT axis of wild amphibians.

Several studies indicate that exposure to nitrate altered rates of amphibian metamorphic development with apparent species-dependent sensitivities (Wyngaarden et al., 1953; Xu and Oldham, 1997; Edwards et al., 2006; Ortiz-Santaliestra and Sparling, 2007; Allran and Karasov, 2009; Wang et al., 2015). Chinese toad (Bufo 
172 gargarizans) tadpoles exposed to a relatively high concentration (100 mg/L) of nitrate

173 exhibited delayed metamorphosis, reduced circulating T4 and T3 levels, down-

174 regulation of dio2 and up-regulation of dio3 mRNA, and partial colloid depletion in

175 thyroid gland follicles (Wang et al., 2015). Interestingly, B. gargarizans exposed to 5 -

$176200 \mathrm{mg} / \mathrm{L}$ nitrate at embryonic stages (when maternally-transferred HPT molecular

177 components are present), exhibited an increased rate of development, down-regulation

178 of transporter genes (solute carrier family 16 member 2 (s/c16a2) and (solute carrier

179 organic anion transporter family, member 1C) s/co1c) and of dio2 and dio3, and an up-

180 regulation of tra (Xie et al., 2019). In this study, T4 levels and trß expression were not

181 affected by nitrate exposure. Similarly, exposure 5 and $50 \mathrm{mg} / \mathrm{L}$ nitrate did not report

182 transcriptional alterations of TH-responsive genes ( $\operatorname{tr} \beta$ and Rana larval keratin type I) in

183 Lithobates catesbeianus (American bullfrog) tadpole tail fin tissue (Hinther et al., 2012).

184 Therefore, it is suggested that nitrate does not interact with $\mathrm{T} 4$, but disrupts gene 185 expression following conversion to reactive nitric oxide; thereby, disrupting essential 186 proteins, and affecting transcription and mRNA stability (Poulsen et al., 2018). The 187 species-specific sensitivities and the molecular mechanisms by which nitrate disrupts 188 the HPT axis in amphibians remains to be elucidated.

$189 \quad 2.1 .2$ Metals

190 Metals, such as lead $(\mathrm{Pb})$, copper $(\mathrm{Cu})$, and cadmium $(\mathrm{Cd})$, are aquatic

191 contaminants associated with agricultural operations (Naveedullah et al., 2013). A major

192 source of metal contamination from agriculture is from the application of fertilizer that is

193 manufactured from phosphate rock, which includes trace levels of metals (Sabiha-

194 Javied et al., 2009). Some metals are anti-thyroidogenic and decrease metamorphic 
195 rate, thereby posing a threat to wild amphibians (Thambirajah et al., 2019). Sublethal

196 concentrations of $\mathrm{Pb}$ has been shown to inhibit metamorphosis in Bufo arenarum

197 (Pérez-Coll et al., 1988, 1990), L. pipiens (Northern leopard frog; Chen et al., 2006),

198 Pelophylax nigromaculatus (Black spotted frog; Huang et al., 2014) and B. gargarizans

199 (Yang et al., 2019). In B. gargarizans, $\mathrm{Pb}$ exposure at $1000 \mu \mathrm{g} / \mathrm{L}$ caused follicular cell

200 hyperplasia and colloid depletion in thyroid glands, increased the transcript levels of

201 dio2, tra, and trß, while decreasing dio3 mRNA levels (Yang et al., 2019).

202 Copper occurs naturally in the environment; however, deposits of anthropogenic

203 Cu reach surface waters from agricultural runoff. Several studies have demonstrated

204 that Cu exposure can delay the rate of metamorphosis in L. pipiens (Chen et al., 2007),

205 L. sphenocephalus (Southern leopard frog; Lance et al. 2012), L. sylvatica (Wood frog;

206 Peles, 2013), B. gargarizans (Chai et al., 2014; Wang et al., 2016; Chai et al., 2017),

207 and B. arabicus (Arabian toad, Barry, 2011). At the histological level, Cu causes

208 follicular hyperplasia in the thyroid gland of B. gargarizans (Wang et al., 2016).

209 Exposure to 32 and $64 \mu \mathrm{g} / \mathrm{L} \mathrm{Cu}$ induced an up-regulation of dio3 expression, but down-

210 regulations of both tra and tr (Wang et al., 2016). Similarly, exposure to $64 \mu \mathrm{g} / \mathrm{L} \mathrm{Cu}$

211 induced down-regulation of dio2, dio3, tra, and $\operatorname{tr} \beta$ mRNA levels in a separate study of

212 B. gargarizans (Chai et al., 2017).

213 Phosphate-based fertilizers contain varying amounts of $\mathrm{Cd}$, and agricultural

214 interventions have been shown to enhance leaching of geogenic $\mathrm{Cd}$ from soil

215 (Hariprasad and Dayanada, 2013). Sub-lethal Cd exposure may have HPT-disrupting

216 effects in amphibians. Cd exposure at 5 and $54 \mu \mathrm{g} / \mathrm{L}$ was found to accelerate

217 metamorphosis in Anaxyrus americanus tadpoles (American toad; James and Little, 
218 2003). In contrast, Cd exposure at $855 \mu \mathrm{g} / \mathrm{L} \mathrm{Cd}$ arrested metamorphosis in Xenopus 219 laevis (African clawed frog; Sharma and Patiño, 2008), and interestingly, these effects 220 were exacerbated in male $X$. laevis tadpoles when estradiol-17ß (E2) was present 221 (Sharma and Patiño, 2010). Sharma and Patiño (2008) also observed a reduction in 222 follicle cell height in $X$. laevis tadpoles. Chronic Cd exposure $(50,100$, and $500 \mu \mathrm{g} / \mathrm{L})$ in

223 B. gargarizans tadpoles caused retarded metamorphosis, follicular hyperplasia of the 224 thyroid, and downregulated dio2, tra, and tr $\beta$ transcripts (Sun et al., 2018). Similarly, 225 metamorphosis was arrested at a pro-metamorphic stage in Pleurodeles waltl (Iberian 226 ribbed newt) exposed to $1.2 \mathrm{mg} / \mathrm{L} \mathrm{Cd}$ (Flament et al., 2003). Several studies reported 227 that Cd decreases plasma T4 levels, without altering T3 levels (reviewed in Buha et al., 228 2018). The direct effect on the thyroid gland is suggested to be due to oxidative stress 229 in mitochondria of follicular cells; thereby, altering production and/or secretion of T4 230 (Buha et al., 2018).

\section{$231 \quad$ 2.2. Fungicides}

The azole fungicides are broad-spectrum fungicides used widely in agriculture.

233 The imidazole fungicide, cyproconazole, adversely affected both the HPT and HPG

234 axes in P. nigromaculata (Zhang W et al., 2019). Chronic cyproconazole exposure

235 caused a decreased rate of metamorphic development and exposure to $1 \mathrm{mg} / \mathrm{L}$

236 cyproconazole reduced colloid and follicles of the thyroid gland. Moreover, T3 and T4,

237 and thyroid-related gene transcript levels were significantly affected in a stage- and

238 concentration-dependent manner (Zhang W et al., 2019). Similarly, the triazole

239 fungicide, triadimefon is the most commonly used agricultural fungicide and has been

240 implicated as having anti-thyroidogenic action in amphibians (Zhang W et al., 2020; Li, 
241 Li et al., 2016). In P. nigromaculatus, 28-day larval exposure affected the rate of

242 metamorphosis and significantly altered transcriptional regulation (Zhang W et al.,

243 2020). In the brain, transcripts of $\operatorname{tsh} \beta$ and dio2 were upregulated, while $\operatorname{tr} \beta$, dio2, matrix

244 metalloproteinase 2, TH-responsive basic leucine zipper transcription factor (TH/bZIP),

245 and sonic hedgehog genes were up-regulated in the intestine (Zhang W et al., 2020).

246 Interestingly, despite the observed inhibitory effects of triadimefon on development, $\mathrm{TH}$ -

247 responsive genes were induced, suggesting a compensatory transcriptional response.

248 Pre-metamorphic (Nieuwkoop and Faber (NF) stage 51) X. laevis tadpoles exposed to

249 triadimefon for 21 days exhibited similar adverse effects (Zhang W et al., 2020). Anti-

250 thyroidogenic effects were observed, including reduced rate of metamorphosis,

251 decreased levels of T3 and T4, and an alteration of HPT-related gene expression. The

252 authors conducted in silico ligand-TR docking computational analyses, which

253 suggested that triadimefon could interact with TRs; however, direct evidence is lacking.

$254 \quad$ Mancozeb is a dithiocarbamate that is extensively used in orchard crops and has

255 been shown to induce adverse effects on TH-related developmental processes in frogs.

256 Mancozeb $(16,80$, and $400 \mu \mathrm{g} / \mathrm{L})$ reduced growth in a concentration-dependent manner

257 in L. pipiens (Shenoy et al., 2009) and induced physical deformities in eye and limb

258 development in A. americanus tadpoles (Harris et al., 2000). TH-disruptive action of

259 mancozeb (e.g., decreasing circulating T4 levels) has been characterized in other

260 vertebrates (Nordby et al., 2005; Axelstad et al., 2011; Pandey and Mohanty, 2015),

261 however, the underlying molecular pathways involved in these effects of fungicides in

262 amphibians have not yet been assessed using more sensitive analytical tools. 
The imidazole prochloraz, is widely used in Asia, Australia, Europe, and South

264 America. It has been shown to delay metamorphosis, elevate T3 levels, and cause

265 thyroid hyperplasia in R. temporaria (European common frog) (Brande-Lavridsen et al.

266 2008). Similarly, $X$. laevis tadpoles exposed to 20,60 and $180 \mu \mathrm{g} / \mathrm{L}$ prochloraz exhibited

267 elevated T4 level and mild follicular cell hypertrophy in thyroid gland histology of the 180

$268 \mu \mathrm{g} / \mathrm{L}$ treatment group (Haselman et al., 2018). These effects were observed without

269 concurrent alteration of T3 level or disruption of metamorphic rate. Therefore, it was

270 suggested that prochloraz exposure interfered with the HPT-axis by altering T4

271 metabolism in the liver and kidney or through affecting the negative-feedback

272 mechanisms. Interestingly, prochloraz has also been implicated in the disruption of

273 other endocrine pathways through aromatase inhibition. Exposure to 115 and $251 \mu \mathrm{g} / \mathrm{L}$

274 prochloraz lowered plasma testosterone levels, disrupted gonadal differentiation, and

275 caused a male-biased sex ratio in $R$. temporaria (Brande-Lavridsen et al., 2008). It was

276 suggested that prochloraz may act through an anti-androgen mode of action (Haselman

277 et al., 2018), but this is far from clear. Given the potential for prochloraz to disrupt both

278 thyroid and gonadal functions, it will be important to determine the mechanisms of

279 action within the context of hormonal crosstalk (Figure 1).

$280 \quad 2.3$ Insectides and acaricides

Organochlorine compounds are established TH disruptors that likely act through

282 competition for binding to TH transport proteins in serum (Cheek et al., 1999b).

283 Dichlorodiphenyltrichloroethane (DDT) is a legacy organochlorine insecticide that

284 persists in the environment with its metabolites, such as

285 dichlorodiphenyldichloroethylene (DDE). Arukwe and Jenssen (2005) reported a down- 
286 regulation of $\operatorname{tr} \beta$ in testis and liver of adult male $R$. temporaria exposed to DDE.

287 Similarly, in larval $R$. temporaria, DDE caused a decrease in tr $\beta$ expression in brain and

288 tail tissue that was negatively correlated with tail length and width (Mortensen et al., 289 2006).

290 The organochlorine miticide dicofol is structurally related to DDT. In binding 291 affinity assays using [125I]T3 and bulfrog transthyretin (TTR), dicofol was found to have 292 a biphasic effect. T3 binidng to TTR was stimulated at low concentrations $(0.4-400$ $293 \mathrm{nM})$ and inhibited at a high concentration (40,000 nM) (Ishihara et al., 2003). Similarly, 294 the organochlorine pesticide, methoxychlor, was originally introduced as a replacement 295 for DDT, but was subsequently banned due, in part, to its endocrine disrupting 296 properties (USEPA, 2004). Fort et al. (2004) explored the sensitivity of $X$. laevis to this 297 compound with endpoints related to the HPT and HPG axes. In tadpoles, methoxychlor 298 exposure delayed metamorphosis, reduced circulating T3 levels, and induced follicular 299 hyperplasia of the thyroid glands at a concentration of $0.1 \mathrm{mg} / \mathrm{L}$. Reproductive assays in 300 adult $X$. laevis indicated that methoxychlor exposure adversely affected fecundity, and 301 reproductive behaviors in both males and females. Both sexes exhibited a 302 concentration-dependent reduction in gonad mass and gamete quantity. In breeding 303 studies where exposed animals were paired with controls, the frequency of amplexus, 304 fertilization, and embryo viability was affected by adult female methoxychlor exposure, 305 and to a lesser extent by male exposure (Fort et al., 2004). Therefore, methoxychlor is 306 an EDC affecting both the HPT and HPG axes in frogs.

307 Organotin compounds have a variety of applications in agriculture as biocidal 308 agents and have also been implicated in disruption of both HPG and HPT axes (Santos- 
309 Silva et al., 2018). The acaricide azocyclotin is an organotin compound extensively used 310 in many agricultural practices due to its wide mode of action of disrupting ATP formation

311 by inhibiting oxidative phosphorylation (Van Leeuwen et al., 2010). A 21 -day exposure

312 of azocyclotin to $X$. laevis tadpoles caused delayed metamorphosis, decreased

313 circulating T3 concentration, and down-regulated expression of thyroid-responsive

314 genes. More specifically, 0.1 and $0.5 \mu \mathrm{g} / \mathrm{L}$ azocyclotin down-regulated the expression of $315 \operatorname{tr} \beta$, dio2, basic transcription element binding protein (bteb), matrix metalloproteinase 2 ,

316 and stromelysin-3 (Li, Cao et al., 2016). Similarly, other organotin pesticides such as

317 fentin hydroxide and fenbutatin oxide, were shown to induce TH disruption by

318 decreasing T3 level in X. laevis tadpoles (Li et al., 2019). Both compounds inhibited

319 metamorphic rate and decreased tr $\beta$, bteb , and dio2 expression; thereby, decreasing

320 T3 level. Transcripts of genes associated with promoting TH production (tsh $\beta$ and

321 slc5a5) (Wang et al., 2013) were up-regulated, suggesting a compensatory

322 transcriptional response to decreased T3 levels. It was also found that fentin hydroxide,

323 but not fenbutatin oxide antagonizes T3-TR $\beta$ complex binding, which affects the TH-

324 dependent transcriptional regulation (Li et al., 2019). The present literature highlights

325 the need for further investigations into the molecular mechanisms of action of specific

326 organotin compounds.

$327 \quad$ Carbaryl is a carbamate insecticide that inactivates acetylcholinesterases.

328 Bridges (2000) demonstrated that carbaryl exposure retarded metamorphosis in $L$.

329 sphenocephalus. In contrast, Boone (2008) reported that carbaryl also accelerated

330 metamorphosis in L. clamitans (green frog) and in A. americanus. In a subsequent

331 study, Boone et al. (2013) revealed that 3 day exposure to $1 \mathrm{mg} / \mathrm{L}$ carbaryl did not affect 
332 L. clamitans metamorphosis, but did induce an up-regulation of $\operatorname{tr} \alpha$ and $\operatorname{tr} \beta$ transcripts in

333 the brain, which persisted for several months following metamorphosis. These studies

334 highlight the importance of exposure timing and life-cycle testing, as well as the

335 potential legacy impact of a transient exposure to EDCs.

336 Since their introduction in the early 1990s, neonicotinoids have become the most

337 commonly used type of insecticide in the world (Jeschke et al., 2011). Although

338 neonicotinoids have been implicated in the disruption of HPT function in lizards (Wang,

339 Xu et al., 2019), birds (Pandey and Mohanty, 2017; 2015), and rats (Ibrahim et al.,

340 2015; Şekeroğlu et al., 2014), there is a relative lack of data concerning their effects in

341 amphibians. In Eremias argus (Mongolian racerunner lizard), three neonicotinoids

342 (dinotefuran, thiamethoxam, and imidacloprid) affected the plasma concentrations of T4,

343 and the transformation of T4 to T3 (Wang, Xu et al., 2019). In larval L. sylvaticus,

344 exposure to imidacloprid at 10 and $100 \mu \mathrm{g} / \mathrm{L}$ (above current environmental levels),

345 increased survival and delayed completion of metamorphosis compared with controls

346 (Robinson et al., 2017), suggesting that the amphibian HPT axis may be altered by

347 neonicotinoids.

$349 \quad 2.4$ Herbicides

$350 \quad 2.4 .1$ Atrazine

The triazine herbicide atrazine is used in $\sim 80$ countries and has been shown to

352 alter TH production in vertebrates (Ghinea et al., 1979; Kornilovskaya et al., 1996;

353 Stoker et al., 2000). The effects of atrazine on amphibians have been well studied,

354 primarily with endpoints related to reproduction. Early studies did not demonstrate 
355 consistent effects of atrazine on the thyroid function in amphibians (Solomon et al.,

356 2008). It is particularly challenging to interpret the current data due to species-specific

357 sensitivities and non-monotonic effects of atrazine. For example, atrazine reduced in

358 vitro corticosterone production in L. catesbeianus, but not X. laevis (Goulet and Hontela,

359 2003). In one study, atrazine exposure delayed metamorphosis at $100 \mu \mathrm{g} / \mathrm{L}$ in $X$. laevis

360 (Freeman and Rayburn, 2005). In contrast, other authors report that atrazine exposure

361 in larval $X$. laevis at similar concentrations $(40-160 \mu \mathrm{g} / \mathrm{L})$ had no effect on the rate of

362 metamorphosis; whereas, 20 and $320 \mu \mathrm{g} / \mathrm{L}$ of atrazine accelerated or delayed

363 metamorphosis, respectively (Sullivan and Spence, 2003). Similarly, in L. clamitans, 10

$364 \mu \mathrm{g} / \mathrm{L}$, but not $25 \mu \mathrm{g} / \mathrm{L}$ atrazine, delayed metamorphosis (Coady et al., 2005). In larval

365 Ambystoma tigrinum (tiger salamander), atrazine exposure delayed and accelerated

366 metamorphosis at $75 \mu \mathrm{g} / \mathrm{L}$ and $250 \mu \mathrm{g} / \mathrm{L}$, respectively (Larson et al., 1998). Both 75 and

$367250 \mu \mathrm{g} / \mathrm{L}$ treatments caused an elevation of plasma T4 in pro-metamorphic (stage-IV),

368 but not at pre-metamorphic (stage-II) larvae (Larson et al., 1998).

369 Several other studies have reported no effects of atrazine on metamorphic

370 endpoints (rate, forelimb emergence, tail resorption) in X. laevis (Carr et al., 2003;

371 Coady et al., 2005; Kloas et al., 2009), Limnodynastes tasmaniensis (spotted grass

372 frog; Spolyarich et al., 2010), A. americanus (Freeman et al., 2005), or L. pipiens (Allran

373 and Karasov, 2000; Orton et al., 2006). In an investigation using sensitive gene

374 expression endpoints, low levels of atrazine $(1.8 \mu \mathrm{g} / \mathrm{L})$ significantly reduced

375 metamorphic success (number of animals reaching metamorphosis) without affecting

376 body weight, snout-vent length, or age at metamorphosis in L. pipiens (Langlois et al.,

377 2010). In the same study, animals that did not metamorphose, exhibited a decreased 
378 expression of dio3 in the tail, suggesting that these animals were attempting to

379 compensate for the anti-metamorphic effects of atrazine through a reduction in $\mathrm{TH}$

380 metabolism. Given the potential for disruption of multiple hormonal axes in some

381 amphibian species, targeted investigations on the cellular and molecular basis of

382 atrazine and other triazines (active ingredients and additives to commercial

383 formulations) is clearly warranted.

\section{$384 \quad$ 2.4.3 Phenylurea herbicides}

Urea-based herbicides are widely used in agriculture to control grasses and

386 broad-leaf weeds and have been associated with chronic toxicity in vertebrates (Marlatt

387 and Martynuik, 2017). While there is evidence that these compounds may disrupt the

388 HPT axis in other vertebrates, there is a relative lack of data for these compounds, 389 especially in amphibians. Diuron is a widely used herbicide of the arylurea class that

390 acts by inhibiting photosynthesis. Diuron and its metabolite, 3,4-dichloroanilin are 391 commonly detected in freshwater ecosystems. Both compounds were shown to disrupt

392 TH-related gene expression and plasma T3 level in L. catesbeianus tadpoles (Freitas et 393 al., 2016). In transgenic $X$. laevis tadpoles expressing the TH/bZIP-gfp reporter gene, 394 linuron exposure significantly increased fluorescence in the head region without T3 co-

395 treatment (Spirhanzlova et al., 2017), inducing TH-like actions. Additionally, linuron has 396 anti-androgenic (Marlatt and Martynuik, 2017) and anti-estrogenic effects (Spirhanzlova 397 et al., 2017). Therefore, phenylurea herbicides having multiple hormonal activities, may 398 represent a particular threat to wild amphibian populations and should be further 399 investigated. 


\subsubsection{Chloroacetanilide herbicides}

Butachlor is a chloroacetanilide herbicide used extensively in rice agriculture that

403 has been identified as a HPT disruptor in vertebrates (Zhu et al. 2014; Li, Wang et al.

404 2016; Shuman-Goodier et al., 2017). Exposure of Rhinella marina (cane toad) tadpoles

405 to butachlor increased expression of tr $\beta$, but did not affect expression of another $\mathrm{TH}-$

406 responsive gene, Krüppel-like factor 9 (klf9) (Shuman-Goodier et al., 2017), and did not

407 affect the rate of metamorphosis. In X. laevis, butachlor promoted metamorphosis,

408 increased T3 and T4 levels and up-regulated tr $\beta$ expression (Li, Wang et al., 2016).

409 Acetochlor is another chloroacetanilide type herbicide and the third-most

410 commonly detected herbicide in surface waters in the USA (Foley et al., 2008).

411 Acetochlor has been implicated in altering the HPT in other vertebrates (Gobiocypris

412 rarus, rare minnow; Li et al., 2009), Rattus norvegicus (rat; Rollerovà et al., 2011),

413 Danio rerio (zebrafish; Yang et al., 2015) and accelerating the rate of metamorphosis in

414 L. pipiens (Cheek et al., 1999a) and X. laevis larvae (Crump et al., 2002). Several

415 studies reported no effect of acetochlor in the absence of exogenous T3 (Cheek et al.,

416 1999a; Crump et al., 2002; Turque et al., 2005). In L. catesbeianus and L. pipiens,

417 exposure to acetochlor during T3-induced metamorphosis resulted in reduced time to

418 forelimb emergence (Cheek et al. 1999a; Velhoen and Helbing, 2001). Acetochlor

419 induced an up-regulation of $\operatorname{tr} \alpha$ and $\operatorname{tr} \beta$ in the brains of premetamorphic L. catesbeianus

420 tadpoles and this up-regulation was enhanced by exogenous T3 treatment (Helbing et

421 al., 2006). Moreover, co-exposure of $L$. catesbeianus to acetochlor and T3 induced a

422 synergistic up-regulation of $\operatorname{tr} \beta$ (Veldhoen and Helbing, 2001). In T3 pre-treated $X$. 
423 laevis tadpoles, acetochlor amplified the transcriptional response of a TH/bZIP

424 promoter-driven eGFP reporter gene in the head region of transgenic tadpoles (Turque

425 et al., 2005). That acetochlor magnifies the T3-induced response for many up-regulated

426 genes and attenuates the response for down- regulated ones, suggests a mechanism of

427 disruption that involves $\mathrm{TH}$-dependent transcriptional regulation. Because acetochlor

428 does not appear to bind directly to TRß (Cheek et al. 1999b), it has been suggested that

429 epigenetic mechanisms may be involved (Crump et al., 2002; Thambirajah et al., 2019).

430 While plausible, this hypothesis remains to be rigorously tested.

431 While acetochlor modulates the HPT axis in amphibians, no studies to date have

432 reported alterations of the HPG axis or other reproductive-related endpoints in

433 acetochlor-treated tadpoles. Acetochlor exposure adversely affects reproduction in rats

434 by interacting with high-affinity to uterine ER (Rollerová et al., 2011, 2000). Thus, the

435 effects of acetochlor on amphibian reproduction should be investigated.

\subsubsection{Glyphosate}

The broad-spectrum organophosphate herbicide glyphosate is used worldwide to 439 kill weeds and grasses in crop fields. The effects of glyphosate on development and

440 growth in several frog species has been reported (e.g., Edge et al., 2011, Edge, Gahl et 441 al, 2014, Edge, Thompson et al., 2014; Bach et al., 2016), but few studies have

442 examined molecular effects to elucidate its mode of action. In the first studies to 443 investigate the molecular effects of glyphosate exposure, Roundup ${ }^{\circledR}$ formulations were 444 shown to disrupt steroidogenesis in mouse Leydig tumour cell line through disruption of 
445 steroid acute regulatory protein (StAR) expression (Walsh et al., 2000). In several frog

446 species, Roundup $\AA$ increased tr $\beta$ mRNA (Howe et al., 2004).

447 Laboratory exposures to the glyphosate-based herbicide VisionMax® had direct

448 effects on the metamorphosis of $L$. sylvaticus tadpoles by decreasing their development

449 rates when exposed to $2.9 \mathrm{mg}$ of acid equivalents (a.e.) per $\mathrm{L}$ (Navarro-Martín et al.,

450 2014). These glyphosate-exposed animals took an additional 7 days to reach

451 metamorphic climax when compared to controls. Tadpoles exposed to VisionMax®

452 were larger in size and in weight with respect to the control group, but no effects on the

453 condition factor were observed. At the molecular level, VisionMax® reduced normal

454 developmental changes in tail tr $\beta$ or dio3, glucocorticoid receptor ( $g r l /)$ mRNA levels in

455 L. sylvaticus tadpoles, suggesting a partial inhibition of the stress axis. The authors

456 hypothesized that the up-regulation of transcripts triggering metamorphosis, such as $\operatorname{tr} \beta$

457 or dio3, could be the result of a compensatory response to prevent developmental delay

458 (Navarro-Martín et al., 2014). These data also suggest that VisionMax® could shift the

459 energy expenditure from development to growth.

460 In an attempt to mimic a agriculturally-relevant scenario, a parallel study was 461 conducted to evaluate the effect of the Roundup WeatherMax®, Roundup Vision ${ }^{\circledR}$ as

462 well as isopropylamine salt of glyphosate (IPA) and the polyethoxylated tallowamine

463 (POEA) surfactant of Vision® by exposing L. sylvaticus tadpoles to two pulse

464 applications (Lanctôt et al. 2014). In this case, developmental rates were not affected 465 and only differences in the condition factor of animals exposed to IPA and POEA were

466 observed, demonstrating that milder effects resulted from environmentally realistic

467 exposures. Nevertheless, this study demonstrated that exposures were able to alter the 
468 developmentally-regulated increases of mRNA levels of key genes controlling

469 development, such as trb, grll, dio2 and dio3, in tail and/or brain. These results reinforce

470 the idea that a compensatory mechanism to regulate $\mathrm{TH}$ levels may occur in tadpoles

471 exposed to glyphosate-based herbicides, but the authors did not measure TH levels.

472 Although no significant effects were found related to growth and development, these

473 results pointed out the need to elucidate the molecular mechanisms of action that could

474 translate to long-term effects on fitness in juveniles or adults exposed to glyphosate-

475 based herbicides during early development.

$476 \quad$ Another study assessed the effects of agriculturally-relevant concentrations of

477 glyphosate-based herbicides on whole ecosystems using in situ split pond design of

478 wetland exposures to Roundup WeatherMax® (Lanctôt et al., 2013). Although small

479 significant differences in growth and development were found in exposed L. sylvaticus

480 tadpoles compared to controlled wetlands, trends were not consistent between years or

481 ponds. Based on this, the authors concluded that pulse exposures of Roundup

482 WeatherMax® may pose minimal risk to larval amphibian development. Interestingly

483 and in line with the laboratory studies, however, exposed tadpoles from some wetlands

484 presented altered mRNA levels of thyroid and stress related genes, supporting the idea

485 that glyphosate-based herbicides have the potential to alter hormonal pathways during

486 tadpole development. These results raised several questions that remain to be

487 answered: 1) would these alterations at the molecular level be translated into

488 functionally biological changes in juvenile or adult later life? 2) Are the observed

489 changes due to direct exposure to herbicides or an indirect consequence of alteration of

490 food resources by these chemicals? 


\subsection{Agrochemical mixtures:}

Considering that agrochemicals are present in the environment in complex

493 mixtures, there is a lack of data examining the effects of environmentally relevant

494 mixtures of agrochemicals on the amphibian HPT axis. Mosconi et al. (2005)

495 documented elevated plasma T3 and T4 frogs (Pelophylax lessonae and P. esculenta

496 esculenta) captured in Italy at agricultural sites compared to those from pristine areas.

497 However, this study did not characterize or quantify the agrochemicals at each site, nor

498 did they examine other TH-related cellular or molecular endpoints. Hayes et al. (2006)

499 were amongst the first to specifically adress the effects of pesticide mixtiures in multiple

500 endocrine systems. In a complex study of L. pipiens and $X$. laevis tadpoles, the effects

501 of low doses four herbicides, two fungicides, and three insecticides used on american

502 cornfields were assessed. The important conclusion was that study of single pesticide

503 exposures is underestimating likely effects on growth, metamorphosis, and stress

504 hormone production. In some cases, mixtures can negate effects, and in other cases

505 mixtures can synergize. Recently, $A$. americanus tadpoles were exposed to water from

506 a retention pond receiving runoff from a pesticide-treated corn operation. Results

507 indicated that the complex mixture of agrochemicals accelerated metamorphic timing

508 and induced a significant up-regulation of $\operatorname{tr} \beta$ and dio3 mRNA in liver at metamorphic

509 climax (Thomson and Langlois, unpublished) indicating the importance of conducting

510 ecotoxicological work in real-world settings. It is clear that future studies must consider

511 relevant mixtures to determine the potential endocerine disruption actions of

512 agrochemicals. 


\section{3. Disruption of growth and metabolism}

515 Life-history theory states that animals have to partition limited resources between

516 growth and reproduction, and hormones control these processes (Figure 1). Since

517 resources are limited there are physiological constraints at the larval and the adult

518 stages that cannot be modified without causing deleterious effects on growth and

519 reproduction (Lardner and Loman, 2003). At the larval stage, disruption of metabolism

520 can have a profound and lasting effect across the lifespan of an organism (Mueller et

521 al., 2015). Indeed, larval development rates determine the period of water availability in

522 temporary ponds and the size and weight at metamorphosis which are all directly linked

523 with mortality. At the adult stage, disruption of metabolism can mimic reduction of

524 resources which is known to increase the risk of mortality associated with reproduction.

525 In such events, skipping reproduction for allocating resources to growth might postpone

526 reproductive event at the following year (Lardner and Loman, 2003) and maintaining

527 reproduction might lead to progeny with reduced growth capacities (Regnault et al.,

528 2018). Amphibians are particularly exposed to agrochemicals through water during

529 periods critical for optimal metabolism, growth or reproduction, (Fan et al., 2007a,

530 2007b; Hayes et al., 2011; Duarte-Guterman et al., 2014).

$531 \quad$ Exposure to agrochemicals during tadpole development has been widely studied

532 and among effects reported alteration of growth has been associated to all types of

533 pesticides. Concerning herbicides, atrazine, and glyphosate have been the most studied

534 for their impacts on tadpole development. Whereas exposures to low environmentally

535 relevant concentrations have not been associated with significant effects on growth

536 (Carr et al., 2003; Coady et al., 2005; Orton et al., 2006) or minor effects (Zaya, Amini, 
537 Whitaker, Ide, 2011; Zaya, Amini, Whitaker, Kohler,Ide, 2011), higher concentrations of

538 atrazine have been shown to decrease snout vent length, body weight (Diana et al.,

539 2000; Sullivan and Spence, 2003), and survival at metamorphosis (Hoskins et al.,

540 2018). Discrepancy between low doses and high doses atrazine have been associated

541 with non-monotonous effects (Diana et al., 2000; Freeman et al., 2005; Coady et al.,

542 2005). For example, exposure to atrazine resulted in a significant acceleration of

543 metamorphosis at $1 \mathrm{mg} / \mathrm{L}$ and a significant increase in the duration of metamorphosis at

$5445 \mathrm{mg} / \mathrm{L}$, whereas no significant difference was observed with $0.1 \mathrm{mg} / \mathrm{L}$ (Brodeur et al.,

545 2009). Many studies have shown that exposures to glyphosate and formulations with

546 POEA and POEA alone increased mortality and decreases size and developmental

547 rates of tadpoles (Edginton et al., 2004; Howe et al., 2004; Relyea, 2004, 2005, 2012;

548 Relyea and Jones, 2009; Jones et al., 2010, 2011; Williams and Semlitsch, 2010;

549 Moore et al., 2012; Lanctôt et al., 2014). Concerning insecticides and fungicides, fewer

550 data are available, but a direct link between exposure to these classes of agrochemicals

551 and growth alterations has been established for the insecticides carbaryl (Boone et al.,

552 2013), a-cypermethrin alone (Xu and Huang, 2017) or in combination with the herbicide

553 oxadiazon (Mesleard et al., 2016), the carbamate methomyl (Trachantong et al., 2017)

554 and the fungicides copper (Peles, 2013), triphenyltin (Higley et al., 2013) and

555 cyproconazole (Zhang W et al., 2019).

556 In several studies, alterations of tadpole growth under pesticide exposure have

557 been associated with metabolic disruption. Tadpoles are required to balance their

558 limited energy reserves for maintenance, growth, metamorphosis, and locomotion, while

559 maintaining adequate energy stores for basal metabolism (Melvin et al., 2016). 
560 Chemical exposure (e.g., naphthenic acids) during sensitive developmental stages can

561 disrupt energy balance in tadpoles (Melvin et al., 2013) by requiring an animal to

562 allocate more energy towards detoxification pathways or altering various metabolic

563 processes that may ultimately influence energy homeostasis (Melvin et al., 2016).

564 Tadpoles exposed pesticide-contaminated water presented decreased levels of

565 biochemical constituents, such as glycogen, suggesting compensatory metabolic

566 mechanisms (Strong et al., 2016, 2017). The relation between atrazine exposure and

567 modification of tadpole metabolism and growth was first studied by Langerveld et al.

568 (2009) in $X$. laevis. In this study, exposure to atrazine at $400 \mu \mathrm{g} / \mathrm{L}$ was associated to a

569 reduction in fat body size, lipid storage organ, suggesting an energy deficit in these

570 tadpoles (Langerveld et al., 2009). In addition, $X$. laevis tadpoles exposed throughout

571 development to 200 or $400 \mu \mathrm{g} / \mathrm{L}$ atrazine, were smaller and had smaller fat bodies.

572 These morphological parameters were associated with an increased transcription of

573 genes involved in the conversion of lipids and proteins into energy and an increase in

574 ADP:ATP ratios at the end of exposure suggesting tadpoles may have had difficulty in

575 maintaining energy homeostasis (Zaya, Amini, Whitaker, Ide, 2011; Zaya, Amini,

576 Whitaker, Kohler, Ide, 2011). These metabolic effects of atrazine were confirmed in $A$.

577 americanus and Hyla versicolor (grey tree frog), where exposed tadpoles displayed

578 perturbations in a number of classes of biological macromolecules, including fatty acids,

579 amino acids, purine nucleosides, pyrimidines, and mono- and di-saccharides. These

580 results suggested that higher concentrations of atrazine ( $\geq 250 \mu \mathrm{g} / \mathrm{L})$ impact energy

581 metabolism of larval amphibians by diverting energy to detoxification, tissue repair and

582 restoring homeostasis (Snyder et al., 2017). Moreover, atrazine, glyphosate, and 
583 quinclorac exposure induced a significant decrease in levels of glycogen, proteins, 584 cholesterol, and total lipids in gill, liver, and muscle in L. catesbeianus (Dornelles and 585 Oliveira, 2014), suggesting that several classes of herbicides might be associated to 586 metabolic disorders. Microhyla fissipes tadpoles (farmland frog) exposed to 60$587120 \mathrm{mg} / \mathrm{L}$ glyphosate-based herbicides showed preference for warm temperatures, 588 exhibited a suppressed growth, and a reduced tail development, together with the 589 down-regulation of carbohydrate and lipid catabolism and the up-regulation of the amino 590 acid catabolism. These results suggested a trade-off between protein synthesis and 591 energy production with respect to amino acid allocation, and provide a metabolic 592 explanation as to why growth was suppressed tadpoles exposed to a glyphosate-based 593 herbicide (Wang, Chang et al., 2019).

$594 \quad$ Molecular mechanisms and hormonal disruption associated with metabolic 595 disorders have been poorly studied in tadpoles. Insight into comprehensive mechanism 596 of pesticide impacts have been pinpointed with the fungicide triphenyltin in $L$. sylvaticus 597 and atrazine in $X$. laevis. In L. sylvaticus larvae that survived to metamorphic climax 598 during exposure to triphenyltin for as long as 100 days, abundance of transcripts of 599 peroxisome proliferator-activated receptors (ppar $\alpha$ and ppary), cytochrome p4504B1 600 (cyp4b1), fatty acid synthase (fas), and lipoprotein lipase (Ip/) were greater than in 601 controls, suggesting that an up-regulation of lipid metabolism might have been 602 important for survival and development of these animals (Higley et al., 2013). In $X$. 603 laevis tadpoles exposed to atrazine, a decrease in glucocorticoid receptor protein and 604 an increase in ppar $\beta$ mRNA were observed, suggesting receptor down-regulation in 605 response to a glucocorticoid surge associated with changes in energy status and lipid 
606 metabolism (Zaya, Amini, Whitaker, Ide, 2011; Zaya, Amini, Whitaker, Kohler, Ide,

607 2011). These results suggest that tadpoles exposed to pesticides undergo a global

608 stress response that might involve the glucocorticoid axis, and increased metabolism

609 may be a compensatory mechanism to promote survival (Higley et al., 2013; Strong et

610 al., 2017).

611 Alteration of tadpole growth has been also associated with parental disruption of

612 metabolism following exposure to endocrine disruptors. Although not yet documented

613 for agrochemical exposure, this pattern has been clearly demonstrated with the

614 polycyclic aromatic hydrocarbon, benzo[a]pyrene $(\mathrm{BaP})$ and the organochlorine,

615 triclosan (TCS). Both acute and chronic exposure to BaP and TCS can induce marked

616 metabolic disorders in Silurana tropicalis (Western clawed frog) associated with

617 impaired lipid and carbohydrate metabolisms (Regnault et al., 2014, 2016, 2018: Usal et

618 al., 2019). Molecular mechanisms clearly demonstrated that the insulin-regulated

619 processes were affected by EDC exposure. Indeed, female S. tropicalis exposed from

620 tadpole stage to BaP or TCS at concentrations of $50 \mathrm{ng} \cdot \mathrm{L}-1$ displayed glucose

621 intolerance syndrome, liver steatosis, liver mitochondrial dysfunction, liver

622 transcriptomic signature, and pancreatic insulin hypersecretion, all typical of a

623 prediabetes state. Moreover, after 1 year of depuration, S. tropicalis that had been

624 exposed to BaP still displayed hepatic disorders and a marked insulin secretory defect

625 resulting in glucose intolerance, suggesting a diabetes-like state (Regnault et al., 2018).

626 The exposed animals produced progeny that metamorphosed later, were smaller and

627 lighter at metamorphosis, and had reduced reproductive success, thus linking metabolic

628 disorders in genitors to tadpole development impairments. These multigenerational 
629 effects have been associated to decreased-lipid levels in eggs, but epigenetic DNA

630 modifications could also occur (Regnault et al., 2018; Usal et al., 2019).

631 Despite the absence of clear correlations between disruption of metabolism by

632 agrochemical in adults and decreased growth capacities of progeny, impacts of

633 pesticide exposure and metabolism impairments in post-metamorphic amphibians have

634 been clearly demonstrated (Van Meter et al., 2018). In adults, disruption of lipid,

635 carbohydrate, and protein metabolism following insecticide exposure has been shown.

636 For example, a decrease in the total lipid content of liver, muscle, testes, and ovaries

637 were observed in Minervarya andamanensis (Andaman frog) with lethal concentration of

638 malathion, whereas exposure to sub-lethal concentrations were associated to an

639 increase in total lipids, free fatty acids, glycerol, and lipase activity (Gurushankara et al.,

640 2007). A negative relationship between $p, p-D D E$ exposure and protein and

641 carbohydrate storage associated with increased energy consumed has been shown in

642 Xenopus muelleri (Müller's clawed frog) (Wolmarans et al., 2018). L. sphenocephala

643 exposed to single, double, or triple pesticide mixtures of bifenthrin (insecticide),

644 metolachlor (herbicide) and triadimefon (fungicide) presented an increase in amino

645 acids and other key metabolites concentrations in liver, suggesting depletion of energy

646 resources (Glinski et al., 2018). Bufo regularis (African toad) exposed to endosulfan

647 showed an increase in serum glucose levels with a concomitant reduction in liver

648 glycogen, indicating disorders in carbohydrate metabolism (Isioma and Lawrence,

649 2013). In addition, an inhibition of normal oxidative metabolism associated to lactic acid

650 accumulation in blood has been shown following exposure of Hoplobatrachus tigerinus 
651 (Indus Valley bullfrog) to the organophosphate phosalone (Ramalingam and 652 Kasinathadurai, 1989).

\section{4. Disruption of sexual differentiation}

654

655

656

657

658

659

660

661

662

663

664

665

666

667

668

669

670

671

672 (presence of intersex, as well as sex reversal as endpoints for studying endocrine

673 disruption). The presence of intersex gonads in frogs have been observed in agricultural 
674 areas and after expsure to atrazine (Hayes, Collins et al., 2002, Hayes, Haston et al.,

675 2002; Hayes et al., 2003; McCoy et al., 2008). In contrast, recent studies (Lambert et

676 al., 2019). showed that frequency of intersex and sexual genotype-phenotype

677 discordance were not correlated in L. clamitans collected from ponds found in

678 underdeveloped landscapes, forested landscapes, or suburban neighborhoods,

679 suggesting that the mechanism by which they occur may be different. Lambert et al.

680 (2019) concluded that the presence of intersex or sex reversal was not associated with

681 land use, suggesting that sex reversal in natural scenarios could be related to multi-

682 stressor responses (including temperature). Clearly, many queations remain

683 unanswered. Directed research must be conducted to link early agrochemical exposure

684 during sexual development with adult frog gonadal status months or years later.

685 Nevertheless, compelling evidence from laboratory and mesocosms studies of

686 feminizing or masculinizing effects in frogs by many environmentally relevant chemicals

687 (such as pharmaceuticals, organic persistent pollutants (PCBs, PBDEs, BPA, PFOS)

688 pesticides and chemical mixtures among others) have been elegantly summarized

689 (Orton and Tyler 2015; Slaby et al., 2019). Many of these compounds are not directly

690 relevant to agricultural practices but serve to demonstrate that sex differentiation

691 processes are sensitive to a range of EDCs. For example, finasteride (5-alpha

692 reductase inhibitor, the enzyme that converts $\mathrm{T}$ to $\mathrm{DHT}$ ) was found to induce feminizing

693 effects, while the aromatase inhibitors flavone (MacKenzie et al., 2003) and fadrozole

694 (Duarte-Guterman et al., 2009) induce masculinization. Therefore, it has been

695 demonstrated that exposure to synthetic steroids or chemicals can affect steroid

696 biosynthesis and disrupt gonadal differentiation in anurans. 
Many pesticides alone or combined in mixtures have the ability to act as

698 androgen receptor (AR) antagonists in vitro and in vivo (Orton et al., 2011; 2012).

699 Feminizing effects has been observed in $S$. tropicalis metamorphs exposed to $9 \mu \mathrm{g} / \mathrm{L}$ of

700 linuron (Orton et al., 2018). The authors conclude that a disruption in the ar/fox/2

701 signaling during gonadal differentiation could be responsible of the observed feminized

702 sex ratio. A comparative toxicogenomics database analysis using transcriptomic

703 datasets suggested that phenylurea herbicides, such as linuron and diuron, exert similar

704 transcriptomic responses as the ones produced by reproductive hormones (Marlatt and

705 Martyniuk 2017). In particular, linuron was found to affect transcripts related to steroid

706 hormone biosynthesis and metabolism of xenobiotics by cytochrome P450, among

707 others. Numerous studies have revealed effects leading to gonadal feminization caused

708 by atrazine in many vertebrate species (Hayes et al. 2011); however, several

709 researchers have failed to demonstrate anuran feminization (reviewed by Orton and

710 Tyler, 2015). In addition to this controversy, the mode of action of atrazine remains

711 unclear and needs to be elucidated. From one side, it was shown that it can perturb

712 steroidogenesis in vitro in amphibian tissues (Goulet and Hontela, 2003; Orton et al.,

713 2009), overstimulate endogenous estrogen production (Crain et al., 1997; Sanderson et

714 al., 2001), up-regulate of brain era mRNA levels as well as disrupting of $5 \beta$-reductase

715 activity which regulates androgen bioavailability by catalyzing the conversion of

716 testosterone to $5 \beta$-dihydrotestosterone (Langlois et al., 2010). On the other hand, in

717 vitro receptor binding assays failed to demonstrate that atrazine directly interact with

718 either the estrogen or androgen receptors (Kojima et al., 2004; Orton et al., 2009) and

719 does not alter aromatase activity in vivo (Rohr \& McCoy, 2010). 
Masculinizing effects in amphibians have also been observed by exposure to

721 androgens and progestogens. Testosterone and trenbolone acetate (a synthetic

722 androgen) are used as growth promotants (to increase muscle growth and appetite) in

723 animal agriculture. Exposure to trenbolone acetate has been shown to masculinize $P$.

724 nigromaculatus (Li et al., 2014) and S. tropicalis (Olmstead et al., 2012), accelerate

725 Müllerian duct regression in X. laevis (Haselman et al., 2016), induce adverse effects on

726 gonadal morphology and differentiation in X. laevis, Bufo viridis, and Hyla arborea

727 (Rozenblut-Kościsty et al., 2019). Although the reproductive effects of trenbolone

728 acetate have been reported, cellular and molecular mechanism of action remains

729 unknown.

730 A very recent study has shown alterations of gonadal development and the 731 synthesis of endogenous hormones in adolescent mice. This study demonstrates a

732 decrease of serum testosterone levels in mice after trenbolone exposure together with

733 the downregulation of the expression of three genes (3b-HSD, P450scc and Cyp 17a1)

734 involved in steroidogenesis (Zhang S et al., 2019). Progesterone (P4) and its synthetic

735 analogue, melengestrol acetate, a veterinary pharmaceutical used to suppress estrus

736 and promote growth in cattle (Orlando and Ellerstad, 2014), were shown to alter

737 expression of sex-steroid-related genes in S. tropicalis embryos (Thomson and

738 Langlois, 2018). Relatively high concentrations of P4 have been implicated in male-

739 biased sex ratios in amphibians (reviewed in Hayes, 1998). The mechanism of

740 androgenic action is possibly through the AR, following biotransformation of P4 to an

741 androgenic steroid (Lutz et al., 2001); however, further investigation is required to

742 confirm this hypothesis. 
Masculinizing effects can be induced not only directly by interacting with ARs, but

744 also indirectly by blockade of estrogen synthesis through aromatase inhibition. For

745 example, when the irreversible aromatase inhibitor 4-hydroxyandrostenedione (4-OHA)

746 was implanted intraperitoneally into L. catesbeianus tadpoles, gonadal abnormalities at

747 the histological level were observed (Yu et al., 1993). These included degenerating

748 ovaries with regressed oocytes (4\%), intersex (17\%), and full differentiation into testes

749 (79\%). Moreover, these gonadal alterations were accompanied by decreased E2 and

750 increased T secretions (Yu et al., 1993). Agrochemicals may exert adverse effects in

751 amphibians by acting through similar mechanisms. For example, the acaracide

752 azocyclotin may have both androgenic and anti-estrogenic action in $X$. laevis (Li et al.,

753 2017). Tadpoles exposed chronically (4 months) to $0.05-0.5 \mathrm{u} \square \mathrm{g} / \mathrm{L}$ exhibited a male-

754 biased sex-ratio, increased T and pregnenolone levels, hermaphroditic gonadal

755 development, and altered gene expression of steroidogenic enzymes (cyp17 and

756 aromatase). Another example can be found in $R$. temporaria in which waterborne

757 exposures from hatch to metamorphosis to the fungicide and aromatase inhibitor

758 prochloraz (115 and $251 \mu \mathrm{g} / \mathrm{L})$ significantly increased the proportion of histological

759 males (80-85.7\%) and hermaphrodites in the final population (Brande-Lavridsen et al., 760 2008).

761 Levonorgestrel (LNG) is a contraceptive progesstagen not usually associated

762 with agriculture, but may be applied to fields through human sewage applications

763 (Tang et al., 2012), and can serve here as a model progestagen. So far, no effects on

764 sex ratios have been observed by exposures to LNG during tadpole development in $X$.

765 laevis and S. tropicalis (Kvarnryd et al 2011, Lorenz et al 2011, Säfholm et al 2016). 
766 However, effects on ovarian and oviductal development were observed in adults,

767 demonstrating that developmental exposures can have long-term effects (Kvarnryd et al

768 2011). These long-term effects seem to be mediated by perturbations in the anti-

769 mullerian hormone and progesterone signalling since LNG exposures altered amh,

770 amhr2, ipgr and mpgr beta mRNA levels in a concentration-, sex- and developmental

771 stage-specific manner (Säfholm et al 2016). Given that synthetiv proestagens can affect

772 development, it will be important to screen agrichemicals for progesterone-like activities

773 in amphibians.

774 Amphibians have divergent patterns of sex determination, sexual differentiation,

775 and development, and therefore, variable responsiveness to hormones and EDCs. The

776 degree of sensitivity a species has to a particular contaminant must be considered when

777 assessing the toxicity of a compound. Piprek et al. (2012) classified amphibians into two

778 categories: highly sensitive and less sensitive species. Rank sensitivities depends not

779 only on the species being studied, but also on the type of EDC being tested (Bridges

780 and Semlitsch, 2000). Another important factor to be considered is the different

781 sensitivities of tadpole life stages (Hogan et al., 2008), indicating that prior to any

782 comparative study, windows of exposure sensitivity assessments are required.

783 Comparative studies have examined the spectrum of amphibian sensitivities to sex

784 steroids and EDCs at both the family and population level. L. pipiens has been reported

785 to be more susceptible to sex reversal and to develop intersex gonads than L. sylvaticus

786 (Mackenzie et al., 2003). However, L. sylvaticus appeared to be more sensitive than $L$.

787 pipiens when developmental endpoints, such as mortality and body size were examined

788 following similar estrogenic exposures (Hogan et al., 2006). When sex ratios and 
789 gonadal histology were assessed in three frog species $(H$. arborea, $B$. viridis and $X$.

790 laevis) exposed to bisphenol A (BPA), the intensity of these effects varied across the

791 three families (Hylidae, Bufonidae and Pipidae) (Tamschick, 2016; Tamschick et al., 792 2016). There may be some relevance of BPA to agriculture, as in some cases, human

793 sewage is being applied to fields as fertilizer, and thus BPA has been detected in

794 agricultural soils (Zhang Z et al., 2015). Another pollutant of concern are polychlorinated 795 biphenyls (PCBs) that have been associated with the use of organic waste as fertilizers

796 in agricultural soils in some countries (Antolín-Rodríguez et el., 2016). A study that

797 assessed effects of PCBs on $X$. laevis found that there was no effect of PCB3 and

798 PCB5 on the proportion of females, but they observed a reduction of males with

799 morphologically normal testes (Qin et al., 2003). Compared to L. clamitans, L. pipiens

800 tadpoles were found to have lower hatching success and survival with higher incidences

801 of edema when exposed to PCBs (Rosenshield et al., 1999). These results suggest that

802 different species sensitivity related to sex differentiation might exist for this compound.

803 Further evidence in $X$. laevis supports variations among population responsiveness 804 when sex ratios were evaluated following E2 exposure (Luong, 2016). In this regard,

805 Orton and Routledge (2011) studied differences in growth, metamorphic development, 806 and sexual differentiation in eggs from Bufo bufo (common toad) collected from sites 807 with different agricultural intensity activities. Their results suggested that maternal 808 exposures and/or in ovo events could have more influence on this developmental 809 process than the tadpole rearing environment. For that reason, they concluded that

810 traditional exposure scenarios (starting at the larval stage) could be missing crucial

811 developmental windows to assess amphibian sensitivity to pollutants. 
One of the challenges to assess the effects of agrochemicals in aquatic

813 organisms is that in most cases, the manufacturers do not provide the information on

814 the full composition of formulations and that the same active compound can be

815 manufactured under different names and by different companies. A clear example is the

816 glyphosate-based herbicides. For example, a study carried out using glyphosate-based

817 herbicides containing POEA as the surfactant (Roundup Original ${ }^{\circledR}$ and Roundup

818 Transorb® formulations) revealed the presence of gonadal abnormalities in L. pipiens,

819 but no effects were observed when glyphosate was tested alone (Howe et al., 2004).

820 However, no observed effects in sex ratios or gonadal abnormalities were observed in

821 L. sylvaticus exposed to VisionMax® under chronic laboratory conditions or to Roundup

822 WeatherMax® under environmental pulse laboratory and field conditions (Lanctôt et al.,

823 2013, 2014, Navarro-Martín et al., 2014).

\section{5. Disruption of anuran vocalization}

Vocalization is the main form of communication in anurans, conveying

826 information on identity, location, and quality. Vocalization is sexually dimorphic, with

827 males producing advertisement calls to attract females for mating. As such, vocalization

828 is influenced by both inter- and intra-sexual selection.

829 Androgens play an important role in male courtship and reproduction (Figure 1).

830 Amplexus, the mating position of anurans, occurs when a male clasps a female to

831 externally fertilize the eggs. In $X$. laevis, amplexus and vocalization can both be induced

832 by human chorionic gonadotropin ( $\mathrm{hCG}$ ), an analog of luteinizing hormone which

833 triggers gonadal steroid production. In castrated adult males, hCG no longer promotes

834 calling. However, exogenous testosterone and dihydrotesterone both restore calling, 
835 and laryngeal muscles are dense in AR, suggesting that the behavior is dependent on

836 testicular androgens (Wetzel and Kelley 1983). Calling was also inhibited by castration

837 and restored with exogenous androgens in several other species such as Hyla cinerea

838 (green tree frog; Burmeister and Wilczynski 2001). In L. pipiens, amplexus and

839 vocalization were induced in intact males with pituitary implants, inhibited in castrates,

840 and restored with testicular implants (Palka and Gorbman 1973).

$841 \quad$ Atrazine has been associated with feminization in frogs. Male $X$. laevis exposed

842 to atrazine from embryo to adult had lower plasma testosterone levels than controls,

843 and were out-competed by controls when attempting to mate with females. They also

844 displayed female-like morphology, including changes in larynx structure, vocalization

845 quality was not assessed (Hayes, Khoury et al., 2010). Vinclozolin, a commonly used

846 fungicide with anti-androgenic effects, affected songs of $X$. laevis. Exposed males

847 experienced a decrease in advertisement calls and an increase in types of call

848 indicating sexual non-receptivity (Hoffmann and Kloas 2010). A recent metabolomic

849 study found that Limnodynastes peronei (striped marsh frog) larvae exposed to atrazine

850 presented alterations in steroidogenesis and cholesterol metabolism and suggested that

851 detected changes in formic acid could be related to alterations in the steroidogenic

852 conversion of androgens into estrogens (Melvin et al., 2018). Exposure to flutamide, a

853 model compound for anti-androgenicity, also reduced advertisement calls (Behrends et

854 al. 2010). As expected, opposite effects were produced with the potent androgen

855 agonist methyl-dihydrotestosterone (MDTH; Hoffmann and Kloas 2012a). This

856 androgen is used in fish aquaculture, so there is a possibility for amphibian exposures

857 to occur because of. water watse disposal. The DDT metabolite DDE was found to 
858 provoke both anti-androgenic-like effects, such as a decrease production of

859 advertisement calls, and estrogenic-like effects, denoted by an increased amount of

860 rasping and a slightly higher bandwidth (Hoffmann and Kloas 2016). This duality was

861 found to be concentration-dependent with lower DDE concentrations (10-11 M) resulting

862 in estrogen-specific responses, while higher concentrations (10-9 M) affected producing

863 anti-androgenic responses.

864 Androgens also contribute to the development of sexually dimorphic calls.

865 Gonadectomized juvenile $X$. laevis of both sexes given testicular implants produce male

866 advertisement calls as adults, but only if the frogs received the implant at $<6$ months

867 old, suggesting a critical period. This is likely related to sexually dimorphic vocal organs,

868 which has been extensively described in $X$. laevis. Nerves in male laryngeal muscles

869 are able to contract and relax more quickly than in females, allowing the production of

870 rapid trills that make up the advertisement calls. Males also have more fast-twitch fibers,

871 while females have more slow-twitch. The surge in THs during metamorphosis is

872 required for the larynx to become androgen-sensitive (Cohen and Kelley 1996;

873 Robertson and Kelley, 1996). As thyroid disruption has been well-studied in tadpoles

874 and juvenile frogs, effects on adult laryngeal biomechanisms and ability to vocalize as

875 adults could be a future area of research. Since atrazine can feminize larynx

876 morphology in adult male frogs (Hayes, Khoury et al. 2010), sound quality is likely to be

877 disrupted.

878 Estrogens can also affect vocal communication. Pharamceutical estrogens enter

879 water through use of contraceptives, but livestock waste is also a major source of

880 estradiol, estrone, and estriol (Hanselman et al., 2003). In male $X$. laevis exposed to 
881 17a-ethinylestradiol (EE2), total calling duration was not affected, but a lower proportion 882 of the calls were advertisement calls, which also had fewer clicks. They also produced

883 more rasping calls, indicating a sexually unreceptive state (Hoffmann and Kloas 2012b).

884 The effects of EE2 were reversed by co-exposure to either tamoxifen or fluverstrant, 885 both pharmaceutical anti-estrogens (Hoffmann and Kloas 2012c). Estrogens had 886 contrasting effects in the Western clawed frog (S. tropicalis); exposure to estradiol and 887 4-tert octylphenol increased the number of calls from males (Schwendiman and Propper 888 2012). This may be due to species differences, or how data was collected. Behaviors 889 were noted by an observer rather than recorded with microphones, which is difficult to 890 do so accurately as calls are underwater. Duration and type of call was also not 891 evaluated in this study. As males produce mating calls, females respond with phonotaxis, or movement 893 relative to acoustic stimuli. Playback experiments have demonstrated hormone894 dependent phonotaxis towards conspecific calls. In Engystomops pustulosus (tungara 895 frogs), injections of hCG led to a dose-dependent increase in plasma E2, as well as 896 increasing phonotactic response to male calls. Phonotaxis could also be induced with 897 exogenous E2 alone, and co-injection of E2 and P4 (Chakraborty and Burmeister 2009). 898 Exposure to recordings of male choruses also increased plasma E2, demonstrating the 899 physiological importance of E2 (Lynch and Wilczynski 2006).

$900 \quad$ Phonotaxis has been poorly studied in the context of endocrine disruption. Direct 901 disruption was tested with female $X$. laevis exposed to the androgen agonist MDHT. 902 Exposed female frogs showed a slightly stronger phonotactic response, although the 903 effect was only significant at one dose on two of four days tested (Hoffmann and Kloas 
904 2012a). Indirect endocrine disruption was tested with $X$. laevis using playbacks of males

905 exposed to EE2 and females preferred calls from control males over exposed

906 (Hoffmann and Kloas 2012b). In both these cases, phonotaxis was measured as time

907 spent near the speaker, which may or may not be due to attraction to the sound, and

908 the effect sizes were small. Since E2 is able to induce phonotaxis, effects of other (anti)-

909 estrogenic compounds on phonotaxis should be examined. While estrogenic

910 compounds may increase phonotactic response, preference and selectivity may be

911 affected. Using established attractive and unattractive playbacks for E. pustulosus

912 female choosiness was found to decrease as receptivity (latency to approach)

913 increased. The less selective frogs were also closer to egg-laying (Lynch et al. 2005).

914 Mate choice is conditional, and a large body of evidence shows that higher quality

915 females show a stronger preference for attractive traits in males (Cotton et al., 2006).

916 For example, larger female Hyperolius marmoratus (African reed frogs) show a stronger

917 preference for low-pitched male calls (Jennions et al., 1995). Female crickets on a high-

918 quality diet show stronger preference for high call rate and responded faster to

919 playbacks with typically preferred features (Hunt et al., 2005). Therefore, negative

920 effects of EDCs on stress and overall health may further disrupt mate choice.

$921 \quad$ Behavioural effects of endocrine disruption have not been as well-studied

922 compared to other endpoints. While underused, behaviour can be an effective indicator

923 as it is the output of integrating neural, endocrine, anatomical, and physiological

924 responses to EDCs. Measurement of behavioural endpoints have the practical

925 advantage of being non-lethal, allowing for repeated measures and long-term studies.

926 Methods should be standardized, especially for more cryptic and subjective behaviors 
927 like phonotaxis. However, vocalization is much more obvious and can be a particularly 928 easy and cost-effective endpoint to measure. Previous studies have largely analyzed

929 acoustic waveforms manually, however the process could be automated for higher 930 throughput and accuracy.

\section{Conclusions and future directions}

Evidence suggests that many classes of agrochemicals, including fertilizers,

934 fungicides, insecticides, acaricides, herbicides, metals, and mixtures negatively affect

935 endocrine signaling in amphibians. In most cases, there is very little known about the

936 mechanisms of actions of these chemicals to lead to adverse outcomes in development,

937 growth, metabolism and reproduction. In numerous cases, investigators observe effects

938 on gene expression endpoints targeting specific endocrine pathways, but it is unclear if

939 these are linked to the apical responses, or the result of the downstream effect on

940 metamorphosis, sexual development, or some other phenotype observed.

941 Thyroidal physiology is essential to development and metamorphosis in anurans,

942 however, the underlying molecular pathways involved in disruption of growth and

943 metamorphosis in amphibians have rarely been assessed using sensitive analytical

944 tools. Given that the general plan of hypthalamo-pituitary control of endocrine

945 physiology is known (Fig, 1), is it surprising that few studies have attempted to quantify

946 effects at the brain and pituitary. Future investigations should further categorize

947 compounds implicated in the alterations of metamorphic rate through analysis of

948 molecular endpoints (e.g., gene expression of TH-responsive genes). A confounding

949 factor when assessing EDCs of the HPT axis is that compounds may induce 
950 developmental stage-dependent differential effects, so experimental designs that

951 employ exposures at multiple life history stages are of paramount importance.

952 Moreover, there are few examples of studies assessing the effects of agrochemicals on

$953 \mathrm{TH}$ levels. There are numerous reasons for this. Firstly, synthesis, interconversion and

954 metabolism of THs by the DIOs is complex and difficult both to assess and interpret.

955 The lack of specificity, bias and imprecision are analytical problems associated with

956 many extraction methods and assays previously utilized for the determination THs.

957 Emerging methods such as ultrahigh-performance liquid chromatography coupled to

958 tandem mass spectrometry that are optimized for amphibians (Luna et al., 2013;

959 Hornung et al., 2015; Hansen et al., 2016) will be essential to comprehensive analysis

960 of thyroid disruption.

$961 \quad$ Many of the agrochemicals lead to disruption of sexual development, including

962 sex reversal. Additionally, more recent data indicate that metabolic disruption may

963 impact reproductive success in subsequent generations. Maternal transfer of chemicals

964 and epigenetic inheritance of potential effects should be investigated in amphibian

965 models. Emerging evidence indicates significant cross-talk between the thyroid and

966 reproductive axes, yet few studies have attempted to determine the consequential

967 effects of disruption of one on the other. Certain chemicals (e.g., atrazine) have been

968 implicated as EDCs of the thyroid, reproductive, and interrenal axes. In contrast, the

969 apparent lack of pleiotropic effects by others (e.g., acetochlor), represents an important

970 gap in our knowledge of cross-talk. Therefore, targeted investigations to characterize

971 the cellular and molecular basis of interactions between endocrine axes are required

972 and would contribute significantly to our understanding of neuroendocrine disruption 
973 processes (Rosenfeld et al., 2017). Future studies must target the molecular pathways

974 underlying sex reversal in tadpoles, and additionally, the consequences for reproductive

975 success. Although sexual differentiation in amphibians is determined genetically, it is

976 highly plastic where sex steroids, environmental factors, or contaminants may interact to

977 affect developmental outcomes. Cause-and-effect studies are clearly lacking. For

978 example, that an estrogenic or antiandrogenic agrochemical can affect sex ratios is

979 suggestive of steroid-mediated disruption, but if that effect was blocked by a known

980 receptor antagonist, it would be strong evidence that indeed the agrochemical was

981 acting via nuclear estrogen or androgen receptor signaling. Given that there are also

982 important differences in the responses of the various taxa and species, it is therefore

983 critical that future studies be designed to determine the mechanisms of action of

984 agrochemicals in Amphibia.

985 Many investigations to date have focused on single-agrochemical exposures.

986 Considering that agrochemicals are present in the environment in complex mixtures,

987 there is a relative lack of data examining the effects of environmentally relevant

988 mixtures. It is therefore pertinent to evaluate the potential interactive effects of

989 agrochemicals on amphibian health at the cellular and molecular levels. Field studies

990 are very informative of the state of amphibian populations; however, it is challenging to

991 establish causality between the exposure scenarios and the observed phenotypes in

992 agricultural field settings, since there are many confounding variables. Therefore, we

993 suggest that laboratory studies be designed in collaboration with field biologists, thus

994 that mechanisms of action of agrochemicals can be established under more relevant 995 scenarios. 
In the broader context, several authors have attempted to link exposure

997 to pollutants, including agrochemicals, to amphibian population declines (Hayes, Falso

998 et al., 2010; Orton and Tyler 2015). On the global scale, population declines are unlikely

999 to be linked to a single agrochemical, or even a single class of compounds. On the

1000 other hand, it is clear that numerous agrochemicals, alone and in mixtures, have

1001 multiple actions to disrupt development, metabolism, stress, and reproduction. Some

1002 agrochemicals result in detrimental effects in the descendant generation. There is thus

1003 the potential for major effects on the physiology of amphibian species. That many

1004 populations of amphibians are exposed to agrochemicals in addition to being subjected

1005 to other ecosystem threats, such as habitat loss and climate change, indicates that

1006 future research must attempt to address both cellular and molecular mechanisms of

1007 endocrine disruption under multiple stressor scenarios in this class of vertebrates.

1008

1009 Acknowledgements

1010 VLT holds the University of Ottawa Research Chair in Neuroendocrinology, PT holds

1011 both a NSERC CREATE-LEADERS and a FRQNT-EcotoQ scholarships, S. Zhang is

1012 the recipient of the OGS and NSERC-CGSM scholarships, and VSL holds the Canada

1013 Research Chair in Ecotoxicogenomics and Endocrine Disruption. VLT also

1014 acknowledges the support of Environment and Chimnal Change Canada for previous

1015 work on pesticides and endocrine disruption in frogs. 
1020

1021

1022

1023

1024

1025

1026

1027

1028

1029

1030

1031

1032

1033

1034

1035

1036

1037

1038

1039

1040

1041

1042

1043

1044

1045

1046

1047

1048

1049

1050

1051

1052

1053

1054

1055

1056

1057

1058

1059

1060

1061

\section{Captions for table and figures}

TABLE 1. Summary of major endocrine-disrupting effects of agricultural fungicide, herbicides, fertilizers and metals in select amphibian species/. Please note that. This table serves to illustrate the range of effects and species. Studies and other key examples can be found in the relevant sections of the main text.

\section{FIGURE 1. Hormonal control system in anurans.}

Corticotropin-releasing factor (CRF) is a dual function neuropeptide (thick black arrows and associated pathways) in anurans. The CRF is secreted from hypothalamic nerve terminals in the median eminence and transported to the pituitary to trigger synthesis and release of thyroid stimulating hormone (TSH) from the pituitary gland. In turn, TSH stimulates the development of the thyroid, leading to initial synthesis and release of THs. It is principally $\mathrm{T} 3$ that drives the positive autoregulation of the $\mathrm{TH}$ receptors to induce metamorphosis-related genes and to reduce the expression of growth-related genes. The CRF system is better known for the neuroendocrine regulation of the stress axis. It stimulated the synthesis and release of adrenocorticotropic hormone (ACTH) from the pituitary, which in turn, stimulates corticosterone (CORT) from the steroidogenic cells of the interrenal (amphibian equivalent to mammalian adrenal cortex embedded within the kidney complex). Corticosteroids negatively feedback at the level of CRF and ACTH to attenuate glucocorticoid synthesis. Corticosterone is the main adrenal steroid in amphibians. While CORT does not drive metamorphosis alone, it can potentiate the actions of THs to accelerate the process. The tripeptide thyrotropinreleasing hormone (TRH) was originally named for that action because of its role in mammals. In anurans, it does not effectively stimulate TSH. On the other hand, it stimulates prolactin (PRL) and growth hormone $(\mathrm{GH}$; grey arrows and associated pathways) to promote tadpole growth. Both $\mathrm{PRL}$ and $\mathrm{GH}$ can negatively regulating several metamorphic processes. Growth hormone-regulated hepatic insulin-like growth factor (IGF) production and IGFs (thin dashed arrow) regulate numerous growth-related processes, and potentially aspects of metamorphosis. Pancreatic hormones, such as insulin (INS), are important for many aspects of growth, metabolism, and metamorphosis (thin black arrows and associated pathways). Recent data indicate that the pancreas is also a target for endocrine disruption. Metabolic disruption can also lead to reduced reproduction. While often not considered along with the thyroid axis, there is accumulating evidence indicating important regulation of the thyroid and reproductive axes (shown by the $\mathrm{X}$; see also Flood et al. 2013 and Duarte-Guterman et al., 2014). The principal stimulatory neuropeptide gonadotropin-releasing hormone $(\mathrm{GnRH})$ stimulates the pituitary synthesize the gonadotropins luteinizing hormone ( $\mathrm{LH})$ and follicle-stimulating hormone (FSH) (hatched arrows and associated pathways). The gonadotropins stimulate development of the ovaries and testes, and drive steroidogenesis. These include progesterone (P4), testosterone (T), 5a-dihydrotestosterone (5a-DHT), and estradiol (E2) (see Vu and 
1062 Trudeau, 2016). The THs can regulate numerous systems within the hypothalamo1063 pituitary-gonadal axis to affect sexual development in tadpoles, or reproductive 1064 processes in adults. Similarly, the sex steroids can impact the thyroid- and growth 1065 systems to modulate metamorphosis. Note that feedback regulation at the 1066 hypothalamus and pituitary by THs, CORT, and sex steroids exists, but is not depicted 1067 on the figure. For further details, refer to documented actions of endocrine disrupting 1068 chemicals in the main text.

1069

1070 
1071

1072

1073

1074

1075

1076

1077

1078

1079

1080

1081

1082

1083

1084

1085

1086

1087

1088

1089

1090

1091

1092

1093

1094

1095

1096

1097

1098

1099

1100

1101

1102

1103

1104

1105

1106

1107

1108

1109

1110

1111

1112

1113

1114

1115

\section{References (Pubmed Format)}

Allran JW, Karasov WH. Effects of atrazine on embryos, larvae, and adults of anuran amphibians. Environ Toxicol Chem. 2001 Apr;20(4):769-75. doi: 10.1897/15515028(2001)020<0769:eoaoel>2.0.co;2. PubMed PMID: 11345452.

Antolín-Rodríguez JM, Sánchez-Báscones M, Martín-Ramos P, Bravo-Sánchez CT, Martín-Gil J. Estimation of PCB content in agricultural soils associated with longterm fertilization with organic waste. Environ Sci Pollut Res Int. 2016 Jun;23(12):12372-83. doi: 10.1007/s11356-016-6439-1. Epub 2016 Mar 16. PubMed PMID: 26983809.

Arukwe A, Jenssen BM. Differential organ expression patterns of thyroid hormone

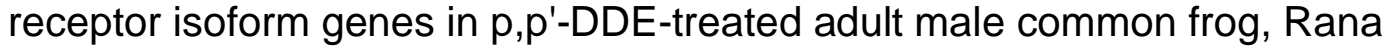
temporaria. Environ Toxicol Pharmacol. 2005 Nov;20(3):485-92. doi: 10.1016/j.etap.2005.05.008. Epub 2005 Jul 11. PubMed PMID: 21783630.

Axelstad M, Boberg J, Nellemann C, Kiersgaard M, Jacobsen PR, Christiansen S, Hougaard KS, Hass U. Exposure to the widely used fungicide mancozeb causes thyroid hormone disruption in rat dams but no behavioral effects in the offspring. Toxicol Sci. 2011 Apr;120(2):439-46. doi: 10.1093/toxsci/kfr006. Epub 2011 Jan 25. PubMed PMID: 21266532.

Bach NC, Natale GS, Somoza GM, Ronco AE. Effect on the growth and development and induction of abnormalities by a glyphosate commercial formulation and its active ingredient during two developmental stages of the South-American Creole frog, Leptodactylus latrans. Environ Sci Pollut Res Int. 2016 Dec;23(23):2395923971. doi: 10.1007/s11356-016-7631-z. Epub 2016 Sep 15. PubMed PMID: 27638798.

Bachtrog D, Mank JE, Peichel CL, Kirkpatrick M, Otto SP, Ashman TL, Hahn MW, Kitano J, Mayrose I, Ming R, Perrin N, Ross L, Valenzuela N, Vamosi JC; Tree of Sex Consortium. Sex determination: why so many ways of doing it? PLoS Biol. 2014 Jul 1;12(7):e1001899. doi: 10.1371/journal.pbio.1001899. eCollection 2014 Jul. Review. PubMed PMID: 24983465; PubMed Central PMCID: PMC4077654.

Barry MJ. Effects of copper, zinc and dragonfly kairomone on growth rate and induced morphology of Bufo arabicus tadpoles. Ecotoxicol Environ Saf. 2011 May;74(4):91823. doi: 10.1016/j.ecoenv.2010.12.014. Epub 2011 Jan 19. PubMed PMID: 21251714.

Behrends T, Urbatzka R, Krackow S, Elepfandt A, Kloas W. Mate calling behavior of male South African clawed frogs (Xenopus laevis) is suppressed by the antiandrogenic endocrine disrupting compound flutamide. Gen Comp Endocrinol. 2010 Sep 1;168(2):269-74. doi: 10.1016/j.ygcen.2010.01.017. PubMed PMID: 20138181.

Boone MD, Hammond SA, Veldhoen N, Youngquist M, Helbing CC. Specific time of exposure during tadpole development influences biological effects of the insecticide carbaryl in green frogs (Lithobates clamitans). Aquat Toxicol. 2013 Apr 15;130-131:139-48. doi: 10.1016/j.aquatox.2012.12.022.

Boone MD. Examining the single and interactive effects of three insecticides on amphibian metamorphosis. Environ Toxicol Chem. 2008 Jul;27(7):1561-8. doi: 10.1897/07-520.1. PubMed PMID: 18260698. 
Brande-Lavridsen N, Christensen-Dalsgaard J, Korsgaard B. Effects of prochloraz and ethinylestradiol on sexual development in Rana temporaria. J Exp Zool A Ecol Genet Physiol. 2008 Aug 1;309(7):389-98. doi: 10.1002/jez.462. PubMed PMID: 18536001.

Bridges CM, Semlitsch RD. Variation in pesticide tolerance of tadpoles among and within species of Ranidae and patterns of amphibian decline. Conservation Biology. 2000 Oct 18;14(5):1490-9. doi: 10.1046/j.1523-1739.2000.99343.x

Brodeur JC, Svartz G, Perez-Coll CS, Marino DJ, Herkovits J. Comparative susceptibility to atrazine of three developmental stages of Rhinella arenarum and influence on metamorphosis: non-monotonous acceleration of the time to climax and delayed tail resorption. Aquat Toxicol. 2009 Jan 31;91(2):161-70. doi: 10.1016/j.aquatox.2008.07.003. PubMed PMID: 18692913.

Buchholz DR, Tomita A, Fu L, Paul BD, Shi YB. Transgenic analysis reveals that thyroid hormone receptor is sufficient to mediate the thyroid hormone signal in frog metamorphosis. Mol Cell Biol. 2004 Oct;24(20):9026-37. doi: 10.1128/MCB.24.20.9026-9037.2004. PubMed PMID:15456876

Buchholz DR. Xenopus metamorphosis as a model to study thyroid hormone receptor function during vertebrate developmental transitions. Mol Cell Endocrinol. 2017;459:64-70. doi:10.1016/j.mce.2017.03.020. PubMed PMID: 28363743.

Buchholz DR, Paul BD, Fu L, Shi YB. Molecular and developmental analyses of thyroid hormone receptor function in Xenopus laevis, the African clawed frog. Gen Comp Endocrinol. 2006;145(1):1-19. doi:10.1016/j.ygcen.2005.07.009. PubMed PMID: 16266705.

Buha A, Matovic V, Antonijevic B, Bulat Z, Curcic M, Renieri EA, Tsatsakis AM, Schweitzer A, Wallace D. Overview of Cadmium Thyroid Disrupting Effects and Mechanisms. Int J Mol Sci. 2018 May 17;19(5). doi: 10.3390/ijms19051501. Review. PubMed PMID: 29772829; PubMed Central PMCID: PMC5983752.

Burmeister SS, Wilczynski W. Social context influences androgenic effects on calling in the green treefrog (Hyla cinerea). Horm Behav. 2001 Dec;40(4):550-8. PubMed PMID: 11716585.

Carr JA, Gentles A, Smith EE, Goleman WL, Urquidi LJ, Thuett K, Kendall RJ, Giesy JP, Gross TS, Solomon KR, Van Der Kraak G. Response of larval Xenopus laevis to atrazine: assessment of growth, metamorphosis, and gonadal and laryngeal morphology. Environmental toxicology and chemistry 2003 Feb; 22 (2):396-405. doi: 10.1002/etc.5620220222. PubMed PMID: 12558173.

Chai L, Wang H, Deng H, Zhao H, Wang W. Chronic exposure effects of copper on growth, metamorphosis and thyroid gland, liver health in Chinese toad, Bufo gargarizans tadpoles. Chemistry and Ecology. 2014;30(7):589-601. doi:

10.1080/02757540.2014.894985

Chai L, Chen A, Deng H, Wang H. Inhibited Metamorphosis and Disruption of Antioxidant Defenses and Thyroid Hormone Systems in Bufo gargarizans Tadpoles Exposed to Copper. Water, Air, \& Soil Pollution. 2017 Sep 1;228(9):359. doi: 10.1007/s11270-017-3548-5

Chakraborty M, Burmeister SS. Estradiol induces sexual behavior in female túngara frogs. Horm Behav. 2009 Jan;55(1):106-12. Doi: 10.1016/j.yhbeh.2008.09.001. Epub 2008 Sep 18. PubMed PMID: 18840446. 
Cheek AO, Ide CF, Bollinger JE, Rider CV, McLachlan JA. Alteration of leopard frog (Rana pipiens) metamorphosis by the herbicide acetochlor. Arch Environ Contam Toxicol. 1999a Jul;37(1):70-7. doi: 10.1007/s002449900491. PubMed PMID: 10341044. del

Cheek AO, Kow K, Chen J, McLachlan JA. Potential mechanisms of thyroid disruption in humans: interaction of organochlorine compounds with thyroid receptor, transthyretin, and thyroid-binding globulin. Environ Health Perspect. 1999b Apr;107(4):273-8. doi: 10.1289/ehp.99107273. PubMed PMID: 10090705; PubMed Central PMCID: PMC1566512.

Chen TH, Gross JA, Karasov WH. Sublethal effects of lead on northern leopard frog (Rana pipiens) tadpoles. Environ Toxicol Chem. 2006 May;25(5):1383-9. PubMed PMID: 16704073. doi: 10.1897/05-356R.1. PubMed PMID: 17665688.

Chen TH, Gross JA, Karasov WH. Adverse effects of chronic copper exposure in larval northern leopard frogs (Rana pipiens). Environ Toxicol Chem. 2007 Jul;26(7):1470-5. PubMed PMID: 17665688.

Coady KK, Murphy MB, Villeneuve DL, Hecker M, Jones PD, Carr JA, Solomon KR, Smith EE, Van Der Kraak G, Kendall RJ, Giesy JP. Effects of atrazine on metamorphosis, growth, laryngeal and gonadal development, aromatase activity, and sex steroid concentrations in Xenopus laevis. Ecotoxicology and environmental safety 2005 Oct; 62 (2):160-173. doi: 10.1016/j.ecoenv.2004.10.010. PubMed PMID: 16112017.

Cohen MA, Kelley DB. Androgen-induced proliferation in the developing larynx of Xenopus laevis is regulated by thyroid hormone. Dev Biol. 1996 Aug 25;178(1):11323. PubMed PMID: 8812113.

Cotton S, Small J, Pomiankowski A. Sexual selection and condition-dependent mate preferences. Curr Biol. 2006 Sep 5;16(17):R755-65. Review. PubMed PMID:16950102.

Crain DA, Guillette LJ Jr, Rooney AA, Pickford DB. Alterations in steroidogenesis in alligators (Alligator mississippiensis) exposed naturally and experimentally to environmental contaminants. Environ Health Perspect. 1997 May;105(5):528-33. PubMed PMID: 9222139; PubMed Central PMCID: PMC1469881.

Crump D, Werry K, Veldhoen N, Van Aggelen G, Helbing CC. Exposure to the herbicide acetochlor alters thyroid hormone-dependent gene expression and metamorphosis in Xenopus laevis. Environ Health Perspect. 2002 Dec;110(12):1199-205. doi: 10.1289/ehp.021101199. PubMed PMID: 12460798; PubMed Central PMCID: PMC1241106.

De Groef B, Decallonne BR, Van der Geyten S, Darras VM, Bouillon R. Perchlorate versus other environmental sodium/iodide symporter inhibitors: potential thyroidrelated health effects. Eur J Endocrinol. 2006 Jul;155(1):17-25. doi: 10.1530/eje.1.02190. Review. PubMed PMID: 16793945.

Denver RJ, Boorse GC, Glennemeier KA. Endocrinology of complex life cycles: amphibians. In: Pfaff, D., Arnold, A., Etgen, A., Fahrbach, S., Moss, R., Rubin, R. (Eds.), Hormones, Brain and Behavior, 2002 vol. 2. Academic Press, San Diego, pp. 469 e513. 
Denver RJ. Neuroendocrinology of amphibian metamorphosis. Curr Top Dev Biol. 2013;103:195-227. doi: 10.1016/B978-0-12-385979-2.00007-1. Review. PubMed PMID: 23347520.

Denver RJ. Structural and functional evolution of vertebrate neuroendocrine stress systems. Ann N Y Acad Sci. 2009 Apr;1163:1-16. doi: 10.1111/j.17496632.2009.04433.x. Review. PubMed PMID: 19456324.

Diana SG, W.J. RJ, Schaeffer DJ, Beckmen KB, Beasley VR. Effects of atrazine on amphibian growth and survival in artificial aquatic communities. Environmental toxicology and chemistry $2000 \mathrm{Dec} ; 19$ (12):2961-2967. doi: 10.1002/etc.5620191217

Dornelles MF, Oliveira GT. Effect of atrazine, glyphosate and quinclorac on biochemical parameters, lipid peroxidation and survival in bullfrog tadpoles (Lithobates catesbeianus). Archives of environmental contamination and toxicology $2014 \mathrm{Apr}$; 66 (3):415-429. doi: 10.1007/s00244-013-9967-4

Duarte-Guterman P, Langlois VS, Hodgkinson K, Pauli BD, Cooke GM, Wade MG, Trudeau VL. The aromatase inhibitor fadrozole and the 5-reductase inhibitor finasteride affect gonadal differentiation and gene expression in the frog Silurana tropicalis. Sex Dev. 2009;3(6):333-41. doi: 10.1159/000280586. Epub 2010 Feb 2. PubMed PMID: 20130388.

Duarte-Guterman P, Navarro-Martin L, Trudeau VL. Mechanisms of crosstalk between endocrine systems: regulation of sex steroid hormone synthesis and action by thyroid hormones. General and comparative endocrinology 2014 Jul 01; 203:69-85. doi: 10.1016/j.ygcen.2014.03.015. PubMed PMID: 24685768.

Edge CB, Gahl MK, Pauli BD, Thompson DG, Houlahan JE. Exposure of juvenile green frogs (Lithobates clamitans) in littoral enclosures to a glyphosate-based herbicide. Ecotoxicol Environ Saf. 2011 Jul;74(5):1363-9. doi: 10.1016/j.ecoenv.2011.04.020. Epub 2011 May 4. PubMed PMID: 21536331.

Edge C, Gahl M, Thompson D, Hao C, Houlahan J. Variation in amphibian response to two formulations of glyphosate-based herbicides. Environ Toxicol Chem. 2014 Nov;33(11):2628-32. doi: 10.1002/etc.2723. Epub 2014 Sep 22. PubMed PMID: 25132334.

Edge C, Thompson D, Hao C, Houlahan J. The response of amphibian larvae to exposure to a glyphosate-based herbicide (Roundup WeatherMax) and nutrient enrichment in an ecosystem experiment. Ecotoxicol Environ Saf. 2014 Nov;109:124-32. doi: 10.1016/j.ecoenv.2014.07.040. Epub 2014 Aug 29. PubMed PMID:25173748.

Edginton AN, Sheridan PM, Stephenson GR, Thompson DG, Boermans HJ. Comparative effects of $\mathrm{pH}$ and Vision herbicide on two life stages of four anuran amphibian species. Environmental toxicology and chemistry 2004 Apr; 23 (4):815822. PubMed PMID: 15095875.

Edwards TM, McCoy KA, Barbeau T, McCoy MW, Thro JM, Guillette LJ Jr. Environmental context determines nitrate toxicity in Southern toad (Bufo terrestris) tadpoles. Aquat Toxicol. 2006 Jun 10;78(1):50-8. 10.1016/j.aquatox.2006.02.003. Epub 2006 Mar 6. PubMed PMID: 16569448. 
Eliceiri BP, Brown DD. Quantitation of endogenous thyroid hormone receptors alpha and beta during embryogenesis and metamorphosis in Xenopus laevis. J Biol Chem.1994 Sep 30;269(39):24459-65. PubMed PMID: 7929109.

Fan W, Yanase T, Morinaga H, Gondo S, Okabe T, Nomura M, Hayes TB, Takayanagi $\mathrm{R}$, Nawata $\mathrm{H}$. Herbicide atrazine activates SF-1 by direct affinity and concomitant co-activators recruitments to induce aromatase expression via promoter II. Biochemical and biophysical research communications 2007a Apr 20; 355 (4):10121018. doi: 10.1016/j.bbrc.2007.02.062. PubMed PMID: 17331471.

Fan W, Yanase T, Morinaga H, Gondo S, Okabe T, Nomura M, Komatsu T, Morohashi $\mathrm{K}$, Hayes TB, Takayanagi R, Nawata $\mathrm{H}$. Atrazine-induced aromatase expression is SF-1 dependent: implications for endocrine disruption in wildlife and reproductive cancers in humans. Environmental health perspectives 2007b May; 115 (5):720727. doi: 10.1289/ehp.9758. PubMed PMID: 17520059; PubMed Central PMCID: PMC1867956.

Flament S, Kuntz S, Chesnel A, Grillier-Vuissoz I, Tankozic C, Penrad-Mobayed M, Auque $G$, Shirali $P$, Schroeder H, Chardard D. Effect of cadmium on gonadogenesis and metamorphosis in Pleurodeles waltl (urodele amphibian). Aquat Toxicol. 2003 Jul 16;64(2):143-53. doi: 10.1016/s0166-445x(03)00042-0. PubMed PMID: 12799107.

Flood DE, Fernandino JI, Langlois VS. Thyroid hormones in male reproductive development: evidence for direct crosstalk between the androgen and thyroid hormone axes.Gen Comp Endocrinol. 2013 Oct 1;192:2-14. doi: 10.1016/j.ygcen.2013.02.038. Epub 2013 Mar 21. Review.PMID: 23524004

Foley ME, Sigler V, Gruden CL. A multiphasic characterization of the impact of the herbicide acetochlor on freshwater bacterial communities. ISME J. 2008 Jan;2(1):56-66. doi: 10.1038/ismej.2007.99. Epub 2007 Nov 8. PubMed PMID: 18180747.

Fort DJ, Guiney PD, Weeks JA, Thomas JH, Rogers RL, Noll AM, Spaulding CD. Effect of methoxychlor on various life stages of Xenopus laevis. Toxicol Sci. 2004 Oct;81(2):454-66. doi: 10.1093/toxsci/kfh243. Epub 2004 Aug 13. PubMed PMID: 15310854.

Freeman JL, Beccue N, Rayburn AL. Differential metamorphosis alters the endocrine response in anuran larvae exposed to T3 and atrazine. Aquat Toxicol. $2005 \mathrm{Nov}$ 10;75(3):263-76. doi: 10.1016/j.aquatox.2005.08.012. Epub 2005 Oct 6. PubMed PMID: 16213604.

Freeman JL, Rayburn AL. Developmental impact of atrazine on metamorphing Xenopus laevis as revealed by nuclear analysis and morphology. Environ Toxicol Chem. 2005 Jul;24(7):1648-53. doi: 10.1897/04-338r.1. PubMed PMID: 16050581.

Freitas JS, Kupsco A, Diamante G, Felicio AA, Almeida EA, Schlenk D. Influence of Temperature on the Thyroidogenic Effects of Diuron and Its Metabolite 3,4-DCA in Tadpoles of the American Bullfrog (Lithobates catesbeianus). Environ Sci Technol. 2016 Dec 6;50(23):13095-13104. doi: 10.1021/acs.est.6b04076. Epub 2016 Nov 9. PubMed PMID: 27787998.

Ghinea E, Simionescu L, Oprescu M. Studies on the action of pesticides upon the endocrines using in vitro human thyroid cells culture and in vivo animal models. I. 
Herbicides--aminotriasole (amitrol) and atrazine. Endocrinologie. 1979 JulSep;17(3):185-90. PubMed PMID: 583081.

Glinski DA, Purucker ST, Van Meter RJ, Black MC, Henderson IW. Endogenous and exogenous biomarker analysis in terrestrial phase amphibians (Lithobates sphenocephala) following dermal exposure to pesticide mixtures. Environ Chem 2018 Nov 7; 16 (1):55-67. doi: 10.1071/EN18163

Goulet BN, Hontela A. Toxicity of cadmium, endosulfan, and atrazine in adrenal steroidogenic cells of two amphibian species, Xenopus laevis and Rana catesbeiana. Environ Toxicol Chem. 2003;22(9):2106-2113. doi:10.1897/02-255

Gurushankara HP, Meenakumari D, Krishnamurthy SV, Vasudev V. Impact of malathion stress on lipid metabolism in Limnonectus limnocharis 2007; 88:50-56. doi: 10.1016/j.pestbp.2006.08.012

Hanselman TA, Graetz DA, Wilkie AC. Manure-borne estrogens as potential environmental contaminants: a review. Environ Sci Technol. 2003 Dec 15;37(24):5471-8. Review. PubMed PMID: 14717153.

Hansen M, Luong X, Sedlak DL, Helbing CC, Hayes T. Quantification of 11 thyroid hormones and associated metabolites in blood using isotope-dilution liquid chromatography tandem mass spectrometry. Anal Bioanal Chem. 2016 Aug;408(20):5429-42. doi: 10.1007/s00216-016-9614-9.. PubMed PMID: 27215639.

Hariprasad NV, Dayananda HS. Environmental Impact due to Agricultural runoff containing Heavy Metals-A Review. International Journal of Scientific and Research Publications: 672.

Harris ML, Chora L, Bishop CA, Bogart JP. Species- and age-related differences in susceptibility to pesticide exposure for two amphibians, Rana pipiens, and Bufo americanus. Bull Environ Contam Toxicol. 2000 Feb;64(2):263-70. doi: 10.1007/s001289910039. PubMed PMID: 10656894.

Haselman JT, Kosian PA, Korte JJ, Olmstead AW, Degitz SJ. Effects of multiple life stage exposure to the fungicide prochloraz in Xenopus laevis: Manifestations of antiandrogenic and other modes of toxicity. Aquat Toxicol. 2018;199:240-251. doi:10.1016/j.aquatox.2018.03.013. PubMed PMID: 29674245; PubMed Central PMCID: PMC6299828.

Haselman JT, Kosian PA, Korte JJ, Olmstead AW, Iguchi T, Johnson RD, Degitz SJ. Development of the Larval Amphibian Growth and Development Assay: effects of chronic 4-tert-octylphenol or $17 \beta$-trenbolone exposure in Xenopus laevis from embryo to juvenile. J Appl Toxicol. 2016 Dec;36(12):1639-1650. doi:10.1002/jat.3330. Epub 2016 May 3. PubMed PMID: 27143402.

Hayes TB. Sex determination and primary sex differentiation in amphibians: genetic and developmental mechanisms. J Exp Zool. 1998 Aug 1;281(5):373-99. Review. PubMed PMID: 9662826.

Hayes TB, Anderson LL, Beasley VR, de Solla SR, Iguchi T, Ingraham H, Kestemont $P$, Kniewald J, Kniewald Z, Langlois VS, Luque EH, McCoy KA, Munoz-de-Toro M, Oka T, Oliveira CA, Orton F, Ruby S, Suzawa M, Tavera-Mendoza LE, Trudeau VL, Victor-Costa $A B$, Willingham $E$. Demasculinization and feminization of male gonads by atrazine: consistent effects across vertebrate classes. The Journal of steroid biochemistry and molecular biology 2011 Oct; 127 (1-2):64-73. doi: 
10.1016/j.jsbmb.2011.03.015. PubMed PMID: 21419222; PubMed Central PMCID: PMC4303243.

Hayes TB, Case P, Chui S, Chung D, Haeffele C, Haston K, Lee M, Mai VP, Marjuoa Y, Parker J, Tsui M. Pesticide mixtures, endocrine disruption, and amphibian declines: are we underestimating the impact? Environ Health Perspect. 2006 Apr;114 Suppl 1(Suppl 1):40-50. doi: 10.1289/ehp.8051. PubMed PMID: 16818245; PubMed Central PMCID: PMC1874187.

Hayes TB, Collins A, Lee M, Mendoza M, Noriega N, Stuart AA, Vonk A. Hermaphroditic, demasculinized frogs after exposure to the herbicide atrazine at low ecologically relevant doses. Proc Natl Acad Sci U S A. 2002 Apr 16;99(8):547680. doi: 10.1073/pnas.082121499. PubMed PMID: 11960004; PubMed Central PMCID: PMC122794.

Hayes TB, Falso P, Gallipeau S, Stice M. The cause of global amphibian declines: a developmental endocrinologist's perspective. J Exp Biol. 2010 Mar 15;213(6):92133. doi: 10.1242/jeb.040865. PubMed PMID: 20190117; PubMed Central PMCID: PMC2829317.

Hayes T, Haston K, Tsui M, Hoang A, Haeffele C, Vonk A. Atrazine-induced hermaphroditism at $0.1 \mathrm{ppb}$ in American leopard frogs (Rana pipiens): laboratory and field evidence. Environ Health Perspect. 2003 Apr;111(4):568-75. doi: 10.1289/ehp.5932. PubMed PMID: 12676617; PubMed Central PMCID: PMC1241446.

Hayes T, Haston K, Tsui M, Hoang A, Haeffele C, Vonk A. Herbicides: feminization of male frogs in the wild. Nature. 2002b. Oct 31;419(6910):895-6. PubMed PMID: 12410298.

Hayes TB, Khoury V, Narayan A, Nazir M, Park A, Brown T, Adame L, Chan E, Buchholz D, Stueve T, Gallipeau S. Atrazine induces complete feminization and chemical castration in male African clawed frogs (Xenopus laevis). Proc Natl Acad Sci U S A. 2010a Mar 9;107(10):4612-7. doi: 10.1073/pnas.0909519107. Epub 2010 Mar 1. PubMed PMID: 20194757; PubMed Central PMCID: PMC2842049

Heimeier RA, Shi YB. Amphibian metamorphosis as a model for studying endocrine disruption on vertebrate development: effect of bisphenol $A$ on thyroid hormone action. Gen Comp Endocrinol. 2010 Sep 1;168(2):181-9. Doi: 10.1016/j.ygcen.2010.02.016. Epub 2010 Feb 21. PubMed PMID: 20178801. Helbing CC, Atkinson BG. 3,5,3'-Triiodothyronine-induced carbamyl-phosphate synthetase gene expression is stabilized in the liver of Rana catesbeiana tadpoles during heat shock. J Biol Chem. 1994 Apr 22;269(16):11743-50. PubMed PMID: 8163471.

Helbing CC, Ovaska K, Ji L. Evaluation of the effect of acetochlor on thyroid hormone receptor gene expression in the brain and behavior of Rana catesbeiana tadpoles. Aquat Toxicol. 2006 Oct 25;80(1):42-51. doi: 10.1016/j.aquatox.2006.07.011. Epub 2006 Sep 1. PubMed PMID: 16949162.

Higley E, Tompsett AR, Giesy JP, Hecker M, Wiseman S. Effects of triphenyltin on growth and development of the wood frog (Lithobates sylvaticus). Aquat Toxicol. 2013 Nov 15;144-145:155-61. doi: 10.1016/j.aquatox.2013.09.029. Epub 2013 Oct 6. PubMed PMID: 24177218. 
Hinther A, Edwards TM, Guillette LJ Jr, Helbing CC. Influence of Nitrate and Nitrite on Thyroid Hormone Responsive and Stress-Associated Gene Expression in Cultured Rana catesbeiana Tadpole Tail Fin Tissue. Front Genet. 2012;3:51. doi: 10.3389/fgene.2012.00051. eCollection 2012. PubMed PMID: 22493607; PubMed Central PMCID: PMC3318185.

Hoffmann F, Kloas W. An environmentally relevant endocrine-disrupting antiandrogen, vinclozolin, affects calling behavior of male Xenopus laevis. Horm Behav. 2010 Sep;58(4):653-9. doi: 10.1016/j.yhbeh.2010.06.008. Epub 2010 Jun 16. PubMed PMID: 20600051.

Hoffmann F, Kloas W. Effects of environmentally relevant concentrations of the xenoandrogen, methyldihydrotestosterone, on male and female mating behavior in Xenopus laevis. Chemosphere. 2012 Jun;87(11):1246-53. Doi: 10.1016/j.chemosphere.2012.01.030. Epub 2012 Feb 17. PubMed PMID: 22342339.

Hoffmann F, Kloas W. Estrogens can disrupt amphibian mating behavior. PLoS One. 2012;7(2):e32097. doi: 10.1371/journal.pone.0032097. Epub 2012 Feb 15. PubMed PMID: 22355410; PubMed Central PMCID: PMC3280221.

Hoffmann F, Kloas W. The antiestrogens tamoxifen and fulvestrant abolish estrogenic impacts of $17 \alpha$-ethinylestradiol on male calling behavior of Xenopus laevis. PLoS One. 2012;7(9):e44715. doi: 10.1371/journal.pone.0044715. Epub 2012 Sep 18. PubMed PMID: 23028589; PubMed Central PMCID: PMC3445530.

Hoffmann F, Kloas W. p,p'-Dichlordiphenyldichloroethylene (p,p'-DDE) can elicit antiandrogenic and estrogenic modes of action in the amphibian Xenopus laevis. Physiol Behav. 2016 Dec 1;167:172-178. doi: 10.1016/j.physbeh.2016.09.012. Epub 2016 Sep 14. PubMed PMID: 27640133.

Hogan NS, Lean DR, Trudeau VL. Exposures to estradiol, ethinylestradiol and octylphenol affect survival and growth of Rana pipiens and Rana sylvatica tadpoles. J Toxicol Environ Health A. 2006 Aug;69(16):1555-69. PubMed PMID: 16854785.

Hogan NS, Duarte P, Wade MG, Lean DR, Trudeau VL. Estrogenic exposure affects metamorphosis and alters sex ratios in the northern leopard frog (Rana pipiens): identifying critically vulnerable periods of development. Gen Comp Endocrinol. 2008 May 1;156(3):515-23. doi: 10.1016/j.ygcen.2008.03.011. Epub 2008 Mar 20.PubMed PMID: 18430423.

Hornung MW, Kosian PA, Haselman JT, Korte JJ, Challis K, Macherla C, Nevalainen E, Degitz SJ. In Vitro, Ex Vivo, and In Vivo Determination of Thyroid Hormone Modulating Activity of Benzothiazoles. Toxicol Sci. 2015 Aug;146(2):254-64. doi: 10.1093/toxsci/kfv090. PubMed PMID: 25953703.

Hoskins T, Dellapina M, Papoulias DM, Boone MD. Effects of larval atrazine exposure in mesocosms on Blanchard's cricket frogs (Acris blanchardi) reared through overwintering and to reproductive age. Chemosphere 2018; 220:845-857. doi: 10.1016/j.chemosphere.2018.12.11.

Howe CM, Berrill M, Pauli BD, Helbing CC, Werry K, Veldhoen N. Toxicity of glyphosate-based pesticides to four North American frog species. Environ Toxicol Chem. 2004 Aug;23(8):1928-38. doi: 10.1897/03-71. PubMed PMID: 15352482.

Huang MY, Duan RY, Ji X. Chronic effects of environmentally-relevant concentrations of lead in Pelophylax nigromaculata tadpoles: Threshold dose and adverse effects. 
Ecotoxicol Environ Saf. 2014 Jun;104:310-6. doi: 10.1016/j.ecoenv.2014.03.027. Epub 2014 Apr 15. PubMed PMID: 24726944.

Hunt J, Brooks R, Jennions MD. Female mate choice as a condition-dependent lifehistory trait. Am Nat. 2005 Jul;166(1):79-92.

Ibrahim K, El-Desouky M, Abou-Yousef H, Gabrowny K, El-Sayed A. Imidacloprid and/or esfenvalerate induce apoptosis and disrupt thyroid hormones in neonatal rats. Global J Biotechnol Biochem. 2015;10:106-12. dio:

10.5829/idosi.gjbb.2015.10.03.1121

Isioma T, Lawrence E. Effects of endosulfan pesticide on toad. Jpn J Vet Res. 2013 Feb;61 Suppl:S67-8. PubMed PMID: 23631157.

Ishihara A, Sawatsubashi S, Yamauchi K. Endocrine disrupting chemicals: interference of thyroid hormone binding to transthyretins and to thyroid hormone receptors. Mol Cell Endocrinol. 2003 Jan 31;199(1-2):105-17. PubMed PMID:12581883.

Ito M. Sex Determination and Differentiation in Frogs. In Reproductive and Developmental Strategies 2018 (pp. 349-366). Springer, Tokyo.

James SM, Little EE. The effects of chronic cadmium exposure on American toad (Bufo americanus) tadpoles. Environ Toxicol Chem. 2003 Feb;22(2):377-80. PubMed PMID: 12558170.

Jennions MD, Backwell PRY, Passmore NI. Repeatability of mate choice: the effect of size in the African painted reed frog, Hyperolius marmoratus. Anim Behav. 1995. Jan;49(1):181-6.

Jeschke $\mathrm{P}$, Nauen $\mathrm{R}$, Schindler M, Elbert A. Overview of the status and global strategy for neonicotinoids. J Agric Food Chem. 2011 Apr 13;59(7):2897-908. doi: 10.1021/jf101303g. Epub 2010 Jun 21. PubMed PMID: 20565065.

Jones DK, Hammond JI, Relyea RA. Roundup and amphibians: the importance of concentration, application time, and stratification. Environmental toxicology and chemistry 2010 Sep; 29 (9):2016-2025. doi: 10.1002/etc.240. PubMed PMID: 20821659.

Jones DK, Hammond JI, Relyea RA. Competitive stress can make the herbicide Roundup $(\mathrm{R})$ more deadly to larval amphibians. Environmental toxicology and chemistry 2011 Feb; 30 (2):446-454. doi: 10.1002/etc.384. PubMed PMID: 21038363.

Kloas W, Lutz I, Springer T, Krueger H, Wolf J, Holden L, Hosmer A. Does atrazine influence larval development and sexual differentiation in Xenopus laevis?. Toxicol Sci. 2009 Feb;107(2):376-84. doi: 10.1093/toxsci/kfn232. Epub 2008 Nov 13. PubMed PMID: 19008211; PubMed Central PMCID: PMC2639758.

Kojima H, Katsura E, Takeuchi S, Niiyama K, Kobayashi K. Screening for estrogen and androgen receptor activities in 200 pesticides by in vitro reporter gene assays using Chinese hamster ovary cells. Environ Health Perspect. 2004 Apr;112(5):524-31. PubMed PMID: 15064155; PubMed Central PMCID: PMC1241915.

Kornilovskaya IN, Gorelaya MV, Usenko VS, Gerbilsky LV, Berezin VA. Histological studies of atrazine toxicity on the thyroid gland in rats. Biomed Environ Sci. 1996 Mar;9(1):60-6. PubMed PMID: 8721629.

Kvarnryd M, Grabic R, Brandt I, Berg C. Early life progestin exposure causes arrested oocyte development, oviductal agenesis and sterility in adult Xenopus tropicalis 
frogs. Aquat Toxicol. 2011 May;103(1-2):18-24. Doi:

10.1016/j.aquatox.2011.02.003. Epub 2011 Feb 15. PubMed PMID: 21392492.

Lance SL, Erickson MR, Flynn RW, Mills GL, Tuberville TD, Scott DE. Effects of chronic copper exposure on development and survival in the southern leopard frog (Lithobates [Rana] sphenocephalus). Environ Toxicol Chem. 2012 Jul;31(7):158794. doi: 10.1002/etc.1849. Epub 2012 May 18. PubMed PMID: 22511547.

Lanctôt C, Navarro-Martín L, Robertson C, Park B, Jackman P, Pauli BD, Trudeau VL. Effects of glyphosate-based herbicides on survival, development, growth and sex ratios of wood frog (Lithobates sylvaticus) tadpoles. II: agriculturally relevant exposures to Roundup WeatherMax $\AA$ and Vision $\AA$ under laboratory conditions. Aquat Toxicol. 2014 Sep;154:291-303. doi: 10.1016/j.aquatox.2014.05.025. Epub 2014 May 28. PubMed PMID: 24912403.

Lanctôt C, Robertson C, Navarro-Martín L, Edge C, Melvin SD, Houlahan J, Trudeau VL. Effects of the glyphosate-based herbicide Roundup WeatherMax® on metamorphosis of wood frogs (Lithobates sylvaticus) in natural wetlands. Aquat Toxicol. 2013 Sep 15;140-141:48-57. doi: 10.1016/j.aquatox.2013.05.012. Epub 2013 May 21. PubMed PMID: 23751794.

Langerveld AJ, Celestine R, Zaya R, Mihalko D, Ide CF. Chronic exposure to high levels of atrazine alters expression of genes that regulate immune and growth-related functions in developing Xenopus laevis tadpoles. Environmental research 2009 May; 109 (4):379-389. doi: 10.1016/j.envres.2009.01.006. PubMed PMID: 19272595.

Langlois VS, Carew AC, Pauli BD, Wade MG, Cooke GM, Trudeau VL. Low levels of the herbicide atrazine alter sex ratios and reduce metamorphic success in Rana pipiens tadpoles raised in outdoor mesocosms. Environ Health Perspect. 2010. Apr;118(4):552-7. doi: 10.1289/ehp.0901418. PubMed PMID: 20368127; PubMed Central PMCID: PMC2854734.

Lambert MR, Tran T, Kilian A, Ezaz T, Skelly DK. Molecular evidence for sex reversal in wild populations of green frogs (Rana clamitans). PeerJ. 2019 Feb 8;7:e6449. doi: 10.7717/peerj.6449. eCollection 2019. PubMed PMID: 30775188; PubMed Central PMCID: PMC6369831.

Lardner B, Loman J. Growth or reproduction? Resource allocation by female frogs Rana temporaria. Oecologia 2003 Dec; 137 (4):541-546. doi: 10.1007/s00442-003-1390-5

Larson DL, McDonald S, Fivizzani AJ, Newton WE, Hamilton SJ. Effects of the herbicide atrazine on Ambystoma tigrinum metamorphosis: duration, larval growth, and hormonal response. Physiol Zool. 1998 Nov-Dec;71(6):671-9. doi: 10.1086/515999. PubMed PMID: 9798254.

Lawniczak AE, Zbierska J, Nowak B, Achtenberg K, Grześkowiak A, Kanas K. Impact of agriculture and land use on nitrate contamination in groundwater and running waters in central-west Poland. Environ Monit Assess. 2016 Mar;188(3):172. doi: 10.1007/s10661-016-5167-9. Epub 2016 Feb 17. PubMed PMID: 26887311; PubMed Central PMCID: PMC4757607.

Leemans M, Couderq S, Demeneix B, Fini JB. Pesticides With Potential Thyroid Hormone-Disrupting Effects: A Review of Recent Data. Front Endocrinol (Lausanne). 2019 Dec 9;10:743. doi: 10.3389/fendo.2019.00743. eCollection 2019. Review. PubMed PMID: 31920955; PubMed Central PMCID: PMC6915086. 
1524

1525

1526

1527

1528

1529

1530

1531

1532

1533

1534

1535

1536

1537

1538

1539

1540

1541

1542

1543

1544

1545

1546

1547

1548

1549

1550

1551

1552

1553

1554

1555

1556

1557

1558

1559

1560

1561

1562

1563

1564

1565

1566

1567

1568
Li M, Cao C, Li S, Gui W, Zhu G. Thyroid endocrine disruption of azocyclotin to Xenopus laevis during metamorphosis. Environ Toxicol Pharmacol. 2016 Apr;43:617. doi: 10.1016/j.etap.2016.02.015. Epub 2016 Feb 24. PubMed PMID: 26970056.

Li S, Li M, Gui W, Wang Q, Zhu G. Disrupting effects of azocyclotin to the hypothalamopituitary-gonadal axis and reproduction of Xenopus laevis. Aquat Toxicol. 2017 Apr;185:121-128. doi: 10.1016/j.aquatox.2017.02.010. Epub 2017 Feb 8. PubMed PMID: 28213302.

Li M, Li S, Yao T, Zhao R, Wang Q, Zhu G. Waterborne exposure to triadimefon causes thyroid endocrine disruption and developmental delay in Xenopus laevis tadpoles. Aquat Toxicol. 2016 Aug;177:190-7. doi: 10.1016/j.aquatox.2016.05.018. Epub 2016 May 24. PubMed PMID: 27289584.

Li S, Li M, Wang Q, Gui W, Zhu G. Exposure to butachlor causes thyroid endocrine disruption and promotion of metamorphosis in Xenopus laevis. Chemosphere. 2016 Jun;152:158-65. doi: 10.1016/j.chemosphere.2016.02.098. Epub 2016 Mar 9. PubMed PMID: 26971167.

Li S, Qiao K, Jiang Y, Wu Q, Coffin S, Gui W, Zhu G. Disruptive effects of two organotin pesticides on the thyroid signaling pathway in Xenopus laevis during metamorphosis. Sci Total Environ. 2019 Dec 20;697:134140. doi: 10.1016/j.scitotenv.2019.134140. Epub 2019 Aug 27. PubMed PMID: 31476497.

Li W, Zha J, Li Z, Yang L, Wang Z. Effects of exposure to acetochlor on the expression of thyroid hormone related genes in larval and adult rare minnow (Gobiocypris rarus). Aquat Toxicol. 2009 Aug 31;94(2):87-93. doi: 10.1016/j.aquatox.2009.06.002. Epub 2009 Jun 10. PubMed PMID: 19577311.

Li YY, Xu W, Chen XR, Lou QQ, Wei WJ, Qin ZF. Low concentrations of $17 \beta$-trenbolone induce female-to-male reversal and mortality in the frog Pelophylax nigromaculatus. Aquat Toxicol. 2015 Jan;158:230-7. doi: 10.1016/j.aquatox.2014.11.017. Epub 2014 Nov 25. PubMed PMID: 25484320.

Lorenz C, Contardo-Jara V, Trubiroha A, Krüger A, Viehmann V, Wiegand C, Pflugmacher S, Nützmann G, Lutz I, Kloas W. The synthetic gestagen Levonorgestrel disrupts sexual development in Xenopus laevis by affecting gene expression of pituitary gonadotropins and gonadal steroidogenic enzymes. Toxicol Sci. 2011 Dec;124(2):311-9. doi: 10.1093/toxsci/kfr241. Epub 2011 Sep 13. PubMed PMID: 21914719.

Luna LG, Coady K, McFadden JR, Markham DA, Bartels MJ. Quantification of total thyroxine in plasma from Xenopus laevis. J Anal Toxicol. 2013 Jul-Aug;37(6):32636. doi: 10.1093/jat/bkt029. PubMed PMID: 23625702.

Luong XG. Differential Estrogen Sensitivity Among Populations of African Clawed Frogs. 2016.PhD Thesis. UC Berkeley. ProQuest ID: Luong_berkeley_0028E_16572. Merritt ID: ark:/13030/m5sn54sx. Retrieved from https://escholarship.org/uc/item/8gf0s157

Lutz LB, Cole LM, Gupta MK, Kwist KW, Auchus RJ, Hammes SR. Evidence that androgens are the primary steroids produced by Xenopus laevis ovaries and may signal through the classical androgen receptor to promote oocyte maturation. Proc Natl Acad Sci U S A. 2001 Nov 20;98(24):13728-33. Epub 2001 Nov 13. PubMed PMID: 11707587; PubMed Central PMCID: PMC61109. 
Lynch KS, Crews D, Ryan MJ, Wilczynski W. Hormonal state influences aspects of female mate choice in the Túngara Frog (Physalaemus pustulosus). Horm Behav. 2006 Apr;49(4):450-7. Epub 2005 Nov 8. PubMed PMID: 16277986; PubMed Central PMCID: PMC2581836.

Lynch KS, Wilczynski W. Social regulation of plasma estradiol concentration in a female anuran. Horm Behav. 2006 Jun;50(1):101-6. Epub 2006 Mar 20. PubMed PMID: 16545384; PubMed Central PMCID: PMC2586932.

Mackenzie CA, Berrill M, Metcalfe C, Pauli BD. Gonadal differentiation in frogs exposed to estrogenic and antiestrogenic compounds. Environ Toxicol Chem. 2003 Oct;22(10):2466-75. PubMed PMID: 14552012.

Marlatt VL, Martyniuk CJ. Biological responses to phenylurea herbicides in fish and amphibians: New directions for characterizing mechanisms of toxicity. Comp Biochem Physiol C Toxicol Pharmacol. 2017 Apr;194:9-21. doi: 10.1016/j.cbpc.2017.01.002. Epub 2017 Jan 19. Review. PubMed PMID: 28109972.

McCoy KA, Bortnick LJ, Campbell CM, Hamlin HJ, Guillette LJ, St Mary CM. Agriculture alters gonadal form and function in the toad Bufo marinus. Environ Health Perspect. 2008 Nov;116(11):1526-32. doi: 10.1289/ehp.11536. Epub 2008 Jul 3. PubMed PMID: 19057706; PubMed Central PMCID: PMC2592273.

Melvin SD, Lanctôtt CM, Craig PM, Moon TW, Peru KM, Headley JV, Trudeau VL. Effects of naphthenic acid exposure on development and liver metabolic processes in anuran tadpoles 2013 Jun; 177:22-27. doi: 10.1016/j.envpol.2013.02.003

Melvin SD, Lanctôt CM, van de Merwe JP, Leusch FD. Altered bioenergetics and developmental effects in striped marsh frog (Limnodynastes peronii) tadpoles exposed to UV treated sewage. Aquat Toxicol. 2016 Jun;175:30-8. doi: 10.1016/j.aquatox.2016.03.010. Epub 2016 Mar 10. PubMed PMID: 26991752

Melvin SD, Leusch FDL, Carroll AR. Metabolite profiles of striped marsh frog (Limnodynastes peronii) larvae exposed to the anti-androgenic fungicides vinclozolin and propiconazole are consistent with altered steroidogenesis and oxidative stress. Aquat Toxicol. 2018 Jun;199:232-239. doi: 10.1016/j.aquatox.2018.04.004. Epub 2018 Apr 11. PubMed PMID: 29660695.

Mesléard F, Gauthier-Clerc M, Lambret P. Impact of the insecticide Alphacypermetrine and herbicide Oxadiazon, used singly or in combination, on the most abundant frog in French rice fields, Pelophylax perezi. Aquat Toxicol. 2016 Jul;176:24-9. doi: 10.1016/j.aquatox.2016.04.004. Epub 2016 Apr 7. PubMed PMID: 27107241.

Miyata K, Ose K. Thyroid Hormone-disrupting Effects and the Amphibian Metamorphosis Assay. J Toxicol Pathol. 2012 Mar;25(1):1-9. doi: 10.1293/tox.25.1. PubMed PMID: 22481853; PubMed Central PMCID: PMC3320151.

Moore LJ, Fuentes L, Rodgers JH, Jr., Bowerman WW, Yarrow GK, Chao WY, Bridges WC, Jr. Relative toxicity of the components of the original formulation of Roundup to five North American anurans. Ecotoxicology and environmental safety 2012 Apr; 78:128-133. doi: 10.1016/j.ecoenv.2011.11.025. PubMed PMID: 22137360.

Mortensen AS, Kortner TM, Arukwe A. Thyroid hormone-dependent gene expression as a biomarker of short-term 1,1-dichloro-2,2-bis(p-chlorophenyl)ethylene (DDE) exposure in European common frog (Rana temporaria) tadpoles. Biomarkers. 2006 
1614

1615

1616

1617

1618

1619

1620

1621

1622

1623

1624

1625

1626

1627

1628

1629

1630

1631

1632

1633

1634

1635

1636

1637

1638

1639

1640

1641

1642

1643

1644

1645

1646

1647

1648

1649

1650

1651

1652

1653

1654

1655

1656

1657
Nov-Dec;11(6):524-37. doi: 10.1080/13547500600806717. PubMed PMID: 17056472.

Mosconi G, Di Rosa I, Bucci S, Morosi L, Franzoni MF, Polzonetti-Magni AM, Pascolini R. Plasma sex steroid and thyroid hormones profile in male water frogs of the Rana esculenta complex from agricultural and pristine areas. Gen Comp Endocrinol. 2005 Jul;142(3):318-24. PubMed PMID: 15935158

Mueller CA, Eme J, Burggren WW, Roghair RD, Rundle SD. Challenges and opportunities in developmental integrative physiology. Comparative biochemistry and physiology Part A, Molecular \& integrative physiology 2015 Jun; 184:113-124. doi: 10.1016/j.cbpa.2015.02.013. PubMed PMID: 25711780; PubMed Central PMCID: PMC4646063.

Navarro-Martín L, Velasco-Santamaría YM, Duarte-Guterman P, Robertson C, Lanctôt C, Pauli B, Trudeau VL. Sexing frogs by real-time PCR: using aromatase (cyp19) as an early ovarian differentiation marker. Sex Dev. 2012;6(6):303-15. doi:

10.1159/000343783. Epub 2012 Nov 14. PubMed PMID: 23154306

Navarro-Martín L, Lanctôt C, Jackman P, Park BJ, Doe K, Pauli BD, Trudeau VL. Effects of glyphosate-based herbicides on survival, development, growth and sex ratios of wood frogs (Lithobates sylvaticus) tadpoles. I: chronic laboratory exposures to VisionMax®. Aquat Toxicol. 2014 Sep;154:278-90. Doi:

10.1016/j.aquatox.2014.05.017. Epub 2014 May 21. PubMed PMID: 24878356.

Naveedullah, Hashmi MZ, Yu C, Shen H, Duan D, Shen C, Lou L, Chen Y. Risk assessment of heavy metals pollution in agricultural soils of siling reservoir watershed in Zhejiang Province, China. Biomed Res Int. 2013;2013:590306. doi: 10.1155/2013/590306. Epub 2013 Sep 15. PubMed PMID: 24151611; PubMed Central PMCID: PMC3787591.

Nordby KC, Andersen A, Irgens LM, Kristensen P. Indicators of mancozeb exposure in relation to thyroid cancer and neural tube defects in farmers' families. Scand J Work Environ Health. 2005 Apr;31(2):89-96. doi: 10.5271/sjweh.855. PubMed PMID: 15864902.

Olmstead AW, Kosian PA, Johnson R, Blackshear PE, Haselman J, Blanksma C, Korte JJ, Holcombe GW, Burgess E, Lindberg-Livingston A, Bennett BA, Woodis KK, Degitz SJ. Trenbolone causes mortality and altered sexual differentiation in Xenopus tropicalis during larval development. Environ Toxicol Chem. 2012 Oct;31(10):2391-8. doi: 10.1002/etc.1965. Epub 2012 Aug 23. PubMed PMID: 22847831.

Orlando EF, Ellestad LE. Sources, concentrations, and exposure effects of environmental gestagens on fish and other aquatic wildlife, with an emphasis on reproduction. Gen Comp Endocrinol. 2014 Jul 1;203:241-9. Doi: 10.1016/j.ygcen.2014.03.038. Epub 2014 Apr 20. Review. PubMed PMID: 24759355.

Ortiz-Santaliestra ME, Sparling DW. Alteration of larval development and metamorphosis by nitrate and perchlorate in southern leopard frogs (Rana sphenocephala). Arch Environ Contam Toxicol. 2007 Nov;53(4):639-46. doi: 10.1007/s00244-006-0277-y. Epub 2007 Jul 20. PubMed PMID: 17657452. 
1658

1659

1660

1661

1662

1663

1664

1665

1666

1667

1668

1669

1670

1671

1672

1673

1674

1675

1676

1677

1678

1679

1680

1681

1682

1683

1684

1685

1686

1687

1688

1689

1690

1691

1692

1693

1694

1695

1696

1697

1698

1699

1700

1701

Orton F, Carr JA, Handy RD. Effects of nitrate and atrazine on larval development and sexual differentiation in the northern leopard frog Rana pipiens. Environ Toxicol Chem. 2006 Jan;25(1):65-71. doi: 10.1897/05-136r.1. PubMed PMID: 16494226.

Orton F, Lutz I, Kloas W, Routledge EJ. Endocrine disrupting effects of herbicides and pentachlorophenol: in vitro and in vivo evidence. Environ Sci Technol. 2009 Mar 15;43(6):2144-50. PubMed PMID: 19368227.

Orton F, Rosivatz E, Scholze M, Kortenkamp A. Competitive androgen receptor antagonism as a factor determining the predictability of cumulative antiandrogenic effects of widely used pesticides. Environ Health Perspect. 2012 Nov;120(11):157884. doi: 10.1289/ehp.1205391. Epub 2012 Sep 10. PubMed PMID: 23008280; PubMed Central PMCID: PMC3556629.

Orton F, Rosivatz E, Scholze M, Kortenkamp A. Widely used pesticides with previously unknown endocrine activity revealed as in vitro antiandrogens. Environ Health Perspect. 2011 Jun;119(6):794-800. doi: 10.1289/ehp.1002895. Epub 2011 Feb 10. PubMed PMID: 21310686; PubMed Central PMCID: PMC3114813.

Orton F, Routledge E. Agricultural intensity in ovo affects growth, metamorphic development and sexual differentiation in the common toad (Bufo bufo). Ecotoxicology. 2011 Jun;20(4):901-11. doi: 10.1007/s10646-011-0658-5. Epub 2011 Mar 30. PubMed PMID: 21448622.

Orton F, Säfholm M, Jansson E, Carlsson Y, Eriksson A, Fick J, Uren Webster T,McMillan T, Leishman M, Verbruggen B, Economou T, Tyler CR, Berg C. Exposure to an anti-androgenic herbicide negatively impacts reproductive physiology and fertility in Xenopus tropicalis. Sci Rep. 2018 Jun 14;8(1):9124. doi:10.1038/s41598-018-27161-2. PubMed PMID: 29904069; PubMed Central PMCID: PMC6002408.

Orton F, Tyler CR. Do hormone-modulating chemicals impact on reproduction and development of wild amphibians? Biol Rev Camb Philos Soc. 2015 Nov;90(4):110017. doi: 10.1111/brv.12147. Epub 2014 Oct 22. Review. PubMed PMID: 25335651.

Palka YS, Gorbman A. Pituitary and testicular influenced sexual behavior in male frogs, Rana pipiens. Gen Comp Endocrinol. 1973 Aug;21(1):148-51. PubMed PMID: 4541987.

Pandey SP, Mohanty B. The neonicotinoid pesticide imidacloprid and the dithiocarbamate fungicide mancozeb disrupt the pituitary-thyroid axis of a wildlife bird. Chemosphere. 2015 Mar;122:227-234. doi: 10.1016/j.chemosphere.2014.11.061. Epub 2014 Dec 12. PubMed PMID: 25496744.

Pandey SP, Mohanty B. Disruption of the hypothalamic-pituitary-thyroid axis on coexposures to dithiocarbamate and neonicotinoid pesticides: Study in a wildlife bird, Amandava amandava. Neurotoxicology. 2017 May;60:16-22. doi:

10.1016/j.neuro.2017.02.010. Epub 2017 Feb 22. PubMed PMID: 28237669.

Peles JD. Effects of chronic aluminum and copper exposure on growth and development of wood frog (Rana sylvatica) larvae. Aquat Toxicol. 2013 Sep 15;140$141: 242-8$. doi: 10.1016/j.aquatox.2013.06.009. Epub 2013 Jun 20. PubMed PMID: 23831691. 
1702

1703

1704

1705

1706

1707

1708

1709

1710

1711

1712

1713

1714

1715

1716

1717

1718

1719

1720

1721

1722

1723

1724

1725

1726

1727

1728

1729

1730

1731

1732

1733

1734

1735

1736

1737

1738

1739

1740

1741

1742

1743

1744

1745

1746

1747
Pérez-Coll CS, Herkovits J. Stage dependent susceptibility to lead in Bufo arenarum embryos. Environ Pollut. 1990;63(3):239-45. doi: 10.1016/0269-7491(90)90157-8. PubMed PMID: 15092319.

Pérez-Coll CS, Herkovits J, Salibián A. Embryotoxicity of lead on Bufo arenarum. Bull Environ Contam Toxicol. 1988 Aug;41(2):247-52. doi: 10.1007/bf01705438. PubMed PMID: 3145046.

Piprek RP, Pecio A, Kubiak JZ, Szymura JM. Differential effects of testosterone and $17 \beta$-estradiol on gonadal development in five anuran species. Reproduction. 2012 Aug;144(2):257-67. doi: 10.1530/REP-12-0048. Epub 2012 May 28. PubMed PMID: 22641770.

Poulsen R, Cedergreen N, Hayes T, Hansen M. Nitrate: An Environmental Endocrine Disruptor? A Review of Evidence and Research Needs. Environ Sci Technol. 2018 Apr 3;52(7):3869-3887. doi: 10.1021/acs.est.7b06419. Epub 2018 Mar 13. Review. PubMed PMID: 29494771.

Qin, Z.F., Zhou, J.M., Chu, S.G., Xu, X.B., 2003. Effects of Chinese domestic polychlorinated biphenyls (PCBs) on gonadal differentiation in Xenopus laevis.

Environ. Health Perspect. 111, 553-556. https://doi.org/10.1289/ehp.5620

Ramalingam K, Kasinathadurai R. Blood carbohydrates and phosalone poisoning in Rana tigrina (Daudin). Archives internationales de physiologie et de biochimie 1989 Oct; 97 (5):369-374.

Regnault C, Usal M, Veyrenc S, Couturier K, Batandier C, Bulteau AL, Lejon D, Sapin A, Combourieu B, Chetiveaux M, Le May C, Lafond T, Raveton M, Reynaud $S$. Unexpected metabolic disorders induced by endocrine disruptors in Xenopus tropicalis provide new lead for understanding amphibian decline. Proc Natl Acad Sci U S A. 2018 May 8;115(19):E4416-E4425. doi: 10.1073/pnas.1721267115. PubMed PMID: 29686083; PubMed Central PMCID: PMC5948982.

Regnault C, Willison J, Veyrenc S, Airieau A, Meresse P, Fortier M, Fournier M, Brousseau P, Raveton M, Reynaud S. Metabolic and immune impairments induced by the endocrine disruptors benzo[a]pyrene and triclosan in Xenopus tropicalis. Chemosphere 2016 Jul; 155:519-527. doi: 10.1016/j.chemosphere.2016.04.047. PubMed PMID: 27153234.

Regnault C, Worms IA, Oger-Desfeux C, MelodeLima C, Veyrenc S, Bayle ML, Combourieu B, Bonin A, Renaud J, Raveton M, Reynaud S. Impaired liver function in Xenopus tropicalis exposed to benzo[a]pyrene: transcriptomic and metabolic evidence. BMC genomics 2014; 15:666. doi: 10.1186/1471-2164-15-666. PubMed PMID: 25103525; PubMed Central PMCID: PMC4141109.

Relyea RA. Growth and survival of five amphibian species exposed to combinations of pesticides. Environ Toxicol Chem 2004 Jul; 23 (7):1737-1742. doi: 10.1897/03-493. PubMed PMID: 15230326.

Relyea RA. The lethal impacts of Roundup and predatory stress on six species of North American tadpoles. Archives of environmental contamination and toxicology 2005 Apr; 48 (3):351-357. doi: 10.1007/s00244-004-0086-0. PubMed PMID: 15886853.

Relyea RA. New effects of Roundup on amphibians: predators reduce herbicide mortality; herbicides induce antipredator morphology. Ecol Appl. 2012 Mar;22(2):634-47. PubMed PMID: 22611860.

Relyea RA, Jones DK. The toxicity of Roundup Original Max to 13 species of 
larval amphibians. Environ Toxicol Chem. 2009 Sep;28(9):2004-8. doi: 10.1897/09-021.1. PubMed PMID: 19405783.

Robertson JC, Kelley DB. Thyroid hormone controls the onset of androgen sensitivity in the developing larynx of Xenopus laevis. Dev Biol. 1996 May 25;176(1):108-23. PubMed PMID: 8654887.

Robinson SA, Richardson SD, Dalton RL, Maisonneuve F, Trudeau VL, Pauli BD, LeeJenkins SS. Sublethal effects on wood frogs chronically exposed to environmentally relevant concentrations of two neonicotinoid insecticides. Environ Toxicol Chem. 2017 Apr;36(4):1101-1109. doi: 10.1002/etc.3739. Epub 2017 Mar 1. PubMed PMID: 28248437.

Rohr JR, McCoy KA. A qualitative meta-analysis reveals consistent effects of atrazine on freshwater fish and amphibians. Environ Health Perspect. 2010 Jan;118(1):2032. doi: 10.1289/ehp.0901164. Erratum in: Environ Health Perspect. 2010 Nov;118(11):A470. PubMed PMID: 20056568; PubMed Central PMCID: PMC2831963.

Rollerová E, Gáspárová Z, Wsólová L, Urbancíková M. Interaction of acetochlor with estrogen receptor in the rat uterus. Acetochlor--possible endocrine modulator?. Gen Physiol Biophys. 2000 Mar;19(1):73-84. PubMed PMID: 10930140.

Rollerová E, Wsolova L, Urbancikova M. Neonatal exposure to herbicide acetochlor alters pubertal development in female wistar rats. Toxicol Mech Methods. 2011 Jun;21(5):406-17. doi: 10.3109/15376516.2010.551554. Epub 2011 Feb 15. PubMed PMID: 21320039.

Rosenfeld CS, Denslow ND, Orlando EF, Gutierrez-Villagomez JM, Trudeau VL. Neuroendocrine disruption of organizational and activational hormone programming in poikilothermic vertebrates. J Toxicol Environ Health B Crit Rev. 2017;20(5):276304. doi:10.1080/10937404.2017.1370083. PubMed PMID: 28895797; PubMed Central PMCID: PMC6174081.

Rosenshield ML, Jofré MB, Karasov WH. Effects of polychlorinated biphenyl 126 on green frog (Rana clamitans) and leopard frog (Rana pipiens) hatching success, development, and metamorphosis. Environ. Toxicol. Chem. 1999. 18(11): 247824862478-2486. doi: 10.1002/etc.5620181114.

Rozenblut-Kościsty B, Ogielska M, Hahn J, Kleemann D, Kossakowski R, Tamschick S, Schöning V, Krüger A, Lutz I, Lymberakis P, Kloas W, Stöck M. Impacts of the synthetic androgen Trenbolone on gonad differentiation and development comparisons between three deeply diverged anuran families. Sci Rep. 2019 Jul 3;9(1):9623. doi: 10.1038/s41598-019-45985-4. PubMed PMID: 31270347; PubMed Central PMCID: PMC6610071.

Sabiha-Javied. Mehmood T, Chaudhry MM, Tufail M, Irfan N. Heavy metal pollution from phosphate rock used for the production of fertilizer in Pakistan. Microchemical Journal. 2009 Jan 1;91(1):94-9. doi: 10.1016/j.microc.2008.08.009

Säfholm M, Jansson E, Fick J, Berg C. Molecular and histological endpoints for developmental reproductive toxicity in Xenopus tropicalis: Levonorgestrel perturbs anti-Müllerian hormone and progesterone receptor expression. Comp Biochem Physiol C Toxicol Pharmacol. 2016 Mar-Apr;181-182:9-18. Doi:

10.1016/j.cbpc.2015.12.001. Epub 2015 Dec 9. PubMed PMID: 26689642. 
1793

1794

1795

1796

1797

1798

1799

1800

1801

1802

1803

1804

1805

1806

1807

1808

1809

1810

1811

1812

1813

1814

1815

1816

1817

1818

1819

1820

1821

1822

1823

1824

1825

1826

1827

1828

1829

1830

1831

1832

1833

1834

1835

1836

1837

Sanderson JT, Letcher RJ, Heneweer M, Giesy JP, van den Berg M. Effects of chloro-striazine herbicides and metabolites on aromatase activity in various human cell lines and on vitellogenin production in male carp hepatocytes. Environ Health Perspect. 2001 Oct;109(10):1027-31. PubMed PMID: 11675267; PubMed Central PMCID: PMC1242079.

Santos-Silva AP, Andrade MN, Pereira-Rodrigues P, Paiva-Melo FD, Soares P, Graceli JB, Dias GRM, Ferreira ACF, de Carvalho DP, Miranda-Alves L. Frontiers in endocrine disruption: Impacts of organotin on the hypothalamus-pituitary-thyroid axis. Mol Cell Endocrinol. 2018 Jan 15;460:246-257. Doi:

10.1016/j.mce.2017.07.038. Epub 2017 Jul 31. Review. PubMed PMID: 28774778.

Schwendiman AL, Propper CR. A common environmental contaminant affects sexual behavior in the clawed frog, Xenopus tropicalis. Physiol Behav. 2012 Jun 25;106(4):520-6. doi: 10.1016/j.physbeh.2012.03.035. Epub 2012 Apr 4. PubMed PMID: 22504493.

Sekeroglu V, Sekeroglu ZA, Demirhan E. Effects of commercial formulations of deltamethrin and/or thiacloprid on thyroid hormone levels in rat serum. Toxicol Ind Health. 2014 Feb;30(1):40-6. doi: 10.1177/0748233712448114. Epub 2012 Jun 7. PubMed PMID: 22677783.

Sharma B, Patiño R. Effects of cadmium, estradiol-17beta and their interaction on gonadal condition and metamorphosis of male and female African clawed frog, Xenopus laevis. Chemosphere. 2010 Apr;79(5):499-505. doi:10.1016/j.chemosphere.2010.02.044. Epub 2010 Mar 17. PubMed PMID: 20299069.

Shenoy K, Cunningham BT, Renfroe JW, Crowley PH. Growth and survival of northern leopard frog (Rana pipiens) tadpoles exposed to two common pesticides. Environ Toxicol Chem. 2009 Jul;28(7):1469-74. doi: 10.1897/08-306.1. Epub 2009 Feb 23. PubMed PMID: 19236124.

Shi Y-B. 2000. Amphibian Metamorphosis. From Morphology to Molecular Biology. John Wiley, New York, NY, USA.

Shuman-Goodier ME, Singleton GR, Propper CR. Competition and pesticide exposure affect development of invasive (Rhinella marina) and native (Fejervarya vittigera) rice paddy amphibian larvae. Ecotoxicology. 2017 Dec;26(10):1293-1304. doi: 10.1007/s10646-017-1854-8. Epub 2017 Sep 21. PubMed PMID: 28936635.

Slaby S, Marin M, Marchand G, Lemiere S. Exposures to chemical contaminants: What can we learn from reproduction and development endpoints in the amphibian toxicology literature? Environ Pollut. 2019 May;248:478-495. doi: 10.1016/j.envpol.2019.02.014. Epub 2019 Feb 4. Review. PubMed PMID: 30831345.

Snyder MN, Henderson WM, Glinski DA, Purucker ST. Biomarker analysis of American toad (Anaxyrus americanus) and grey tree frog (Hyla versicolor) tadpoles following exposure to atrazine 2017 Jan; 182:184-193. doi: 10.1016/j.aquatox.2016.11.018 Solomon KR, Carr JA, Du Preez LH, Giesy JP, Kendall RJ, Smith EE, Van Der Kraak GJ. Effects of atrazine on fish, amphibians, and aquatic reptiles: a critical review. Crit Rev Toxicol. 2008;38(9):721-72. doi: 10.1080/10408440802116496 . Review. PubMed PMID: 18941967. 
Spirhanzlova P, De Groef B, Nicholson FE, Grommen SVH, Marras G, Sébillot A, Demeneix BA, Pallud-Mothré S, Lemkine GF, Tindall AJ, Du Pasquier D. Using short-term bioassays to evaluate the endocrine disrupting capacity of the pesticides linuron and fenoxycarb. Comp Biochem Physiol C Toxicol Pharmacol. 2017 Oct;200:52-58. doi: 10.1016/j.cbpc.2017.06.006. Epub 2017 Jun 17. PubMed PMID: 28634053.

Spolyarich N, Hyne R, Wilson S, Palmer C, Byrne M. Growth, development and sex ratios of Spotted Marsh Frog (Limnodynastes tasmaniensis) larvae exposed to atrazine and a herbicide mixture. Chemosphere. 2010 Feb;78(7):807-13. doi: 10.1016/j.chemosphere.2009.11.048. Epub 2009 Dec 30. PubMed PMID: 20044125.

Stoker TE, Laws SC, Guidici DL, Cooper RL. The effect of atrazine on puberty in male Wistar rats: an evaluation in the protocol for the assessment of pubertal development and thyroid function. Toxicological Sciences. 2000 Nov 1;58(1):50-9. doi: 10.1093/toxsci/58.1.50. PubMed PMID: 11053540.

Strong RJ, Halsall CJ, Ferenčík M, Jones KC, Shore RF, Martin FL. Biospectroscopy reveals the effect of varying water quality on tadpole tissues of the common frog (Rana temporaria). Environ Pollut. 2016 Jun;213:322-337. doi: 10.1016/j.envpol.2016.02.025. Epub 2016 Feb 27. PubMed PMID: 26925755.

Strong R, Martin FL, Jones KC, Shore RF, Halsall CJ. Subtle effects of environmental stress observed in the early life stages of the Common frog, Rana temporaria. Sci Rep. 2017 Mar 20;7:44438. doi: 10.1038/srep44438. PubMed PMID: 28317844; PubMed Central PMCID: PMC5357840

Sullivan KB, Spence KM. Effects of sublethal concentrations of atrazine and nitrate on metamorphosis of the African clawed frog. Environ Toxicol Chem. 2003 Mar;22(3):627-35. doi: 10.1002/etc.5620220323. PubMed PMID: 12627652.

Sun $\mathrm{N}$, Wang H, Ju Z, Zhao H. Effects of chronic cadmium exposure on metamorphosis, skeletal development, and thyroid endocrine disruption in Chinese toad Bufo gargarizans tadpoles. Environ Toxicol Chem. 2018 Jan;37(1):213-223. doi: 10.1002/etc.3947. PubMed PMID: 28799665.

Tang T, Shi T, Li D, Xia J, Hu Q, Cao Y. Adsorption properties and degradation dynamics of endocrine-disrupting chemical levonorgestrel in soils. J Agric Food Chem. 2012 Apr 25;60(16):3999-4004. doi: 10.1021/jf300479z. Epub 2012 Apr 10. PubMed PMID: 22471977.

Tamschick S, Rozenblut-Kościsty B, Ogielska M, Kekenj D, Gajewski F, Krüger A, Kloas W, Stöck M. The plasticizer bisphenol A affects somatic and sexual development, but differently in pipid, hylid and bufonid anurans. Environ Pollut. 2016 Sep;216:282-291. doi: 10.1016/j.envpol.2016.05.091. Epub 2016 Jun 7. PubMed PMID: 27285164.

Tamschick S. Sex-linked molecular markers and their application to endocrine disruption research in amphibians. 2016. PhD Thesis. http://dx.doi.org/10.18452/17649

Thambirajah AA, Koide EM, Imbery JJ, Helbing CC. Contaminant and Environmental Influences on Thyroid Hormone Action in Amphibian Metamorphosis. Front Endocrinol (Lausanne). 2019;10:276. doi: 10.3389/fendo.2019.00276. eCollection 2019. Review. PubMed PMID: 31156547; PubMed Central PMCID: PMC6530347. 
1884

1885

1886

1887

1888

1889

1890

1891

1892

1893

1894

1895

1896

1897

1898

1899

1900

1901

1902

1903

1904

1905

1906

1907

1908

1909

1910

1911

1912

1913

1914

1915

1916

1917

1918

1919

1920

1921

1922

1923

1924

1925

1926

1927

1928

Thomson P, Langlois VS. Developmental profiles of progesterone receptor transcripts and molecular responses to gestagen exposure during Silurana tropicalis early development. Gen Comp Endocrinol. 2018 Sep 1;265:4-14. Doi: 10.1016/j.ygcen.2018.05.017. Epub 2018 May 18. PubMed PMID: 29778442.

Tonacchera M, Pinchera A, Dimida A, Ferrarini E, Agretti P, Vitti P, Santini F, Crump K, Gibbs J. Relative potencies and additivity of perchlorate, thiocyanate, nitrate, and iodide on the inhibition of radioactive iodide uptake by the human sodium iodide symporter. Thyroid. 2004 Dec;14(12):1012-9. doi: 10.1089/thy.2004.14.1012. PubMed PMID: 15650353.

Trachantong W, Saenphet S, Saenphet K, Chaiyapo M. Lethal and sublethal effects of a methomyl-based insecticide in Hoplobatrachus rugulosus. J Toxicol Pathol. 2017 Jan;30(1):15-24. doi: 10.1293/tox.2016-0039. Epub 2016 Oct 21. PubMed PMID: 28190921; PubMed Central PMCID: PMC5293688.

Turque N, Palmier K, Le Mével S, Alliot C, Demeneix BA. A rapid, physiologic protocol for testing transcriptional effects of thyroid-disrupting agents in premetamorphic Xenopus tadpoles. Environ Health Perspect. 2005 Nov;113(11):1588-93. doi: 10.1289/ehp.7992. PubMed PMID: 16263516; PubMed Central PMCID: PMC1310923.

Usal M, Regnault C, Veyrenc S, Couturier K, Batandier C, Bulteau AL, Lejon D, Combourieu B, Lafond T, Raveton M, Reynaud S. Concomitant exposure to benzo[a]pyrene and triclosan at environmentally relevant concentrations induces metabolic syndrome with multigenerational consequences in Silurana (Xenopus) tropicalis. Sci Total Environ. 2019 Nov 1;689:149-159. doi:

10.1016/j.scitotenv.2019.06.386. Epub 2019 Jun 25. PubMed PMID: 31271984.

USEPA. Methoxychlor Reregistration Eligibility Decision (RED). 2004 EPA Publication No. EPA 738-R-04-010. Washington DC.

Van Leeuwen T, Van Pottelberge S, Tirry L. Comparative acaricide susceptibility and detoxifying enzyme activities in field-collected resistant and susceptible strains of Tetranychus urticae. Pest Manag Sci. 2005 May;61(5):499-507. doi: 10.1002/ps.1001. PubMed PMID: 15657956.

Van Meter RJ, Glinski DA, Purucker ST, Henderson WM. Influence of exposure to pesticide mixtures on the metabolomic profile in post-metamorphic green frogs (Lithobates clamitans). The Science of the total environment 2018 May 15; 624:1348-1359. doi: 10.1016/j.scitotenv.2017.12.175

Veldhoen N, Helbing CC. Detection of environmental endocrine-disruptor effects on gene expression in live Rana catesbeiana tadpoles using a tail fin biopsy technique.Environ Toxicol Chem. 2001 Dec;20(12):2704-8. PubMed PMID: 11764152.

Vu M, Trudeau VL. Neuroendocrine control of spawning in amphibians and its practical applications. Gen Comp Endocrinol. 2016 Aug 1;234:28-39. doi: 10.1016/j.ygcen.2016.03.024. Epub 2016 Mar 21. PubMed PMID: 27013378.

Wagner N, Veith M, Lötters S, Viertel B. Population and life-stage-specific effects of two herbicide formulations on the aquatic development of European common frogs (Rana temporaria). Environ Toxicol Chem. 2017 Jan;36(1):190-200. doi: 10.1002/etc.3525. Epub 2016 Jul 29. PubMed PMID: 27291460. 
1929

1930

1931

1932

1933

1934

1935

1936

1937

1938

1939

1940

1941

1942

1943

1944

1945

1946

1947

1948

1949

1950

1951

1952

1953

1954

1955

1956

1957

1958

1959

1960

1961

1962

1963

1964

1965

1966

1967

1968

1969

1970

1971

1972

1973

1974
Walsh LP, McCormick C, Martin C, Stocco DM. Roundup inhibits steroidogenesis by disrupting steroidogenic acute regulatory (StAR) protein expression. Environ Health Perspect. 2000 Aug;108(8):769-76. doi: 10.1289/ehp.00108769. PubMed PMID: 10964798; PubMed Central PMCID: PMC1638308.

Wang $\mathrm{C}$, Liang $\mathrm{G}$, Chai $\mathrm{L}$, Wang $\mathrm{H}$. Effects of copper on growth, metamorphosis and endocrine disruption of Bufo gargarizans larvae. Aquat Toxicol. 2016 Jan;170:2430. doi: 10.1016/j.aquatox.2015.10.023. Epub 2015 Nov 5. PubMed PMID: 26587739.

Wang Q, Liang K, Liu J, Yang L, Guo Y, Liu C, Zhou B. Exposure of zebrafish embryos/larvae to TDCPP alters concentrations of thyroid hormones and transcriptions of genes involved in the hypothalamic-pituitary-thyroid axis. Aquat Toxicol. 2013 Jan 15;126:207-13. doi: 10.1016/j.aquatox.2012.11.009. Epub 2012 Nov 19. PubMed PMID: 23220413.

Wang M, Chai L, Zhao H, Wu M, Wang H. Effects of nitrate on metamorphosis, thyroid and iodothyronine deiodinases expression in Bufo gargarizans larvae. Chemosphere. 2015 Nov;139:402-9. doi: 10.1016/j.chemosphere.2015.07.037. Epub 2015 Jul 24. PubMed PMID: 26210189.

Wang Y, Xu P, Chang J, Li W, Yang L, Tian H. Unraveling the toxic effects of neonicotinoid insecticides on the thyroid endocrine system of lizards. Environ Pollut. 2019 Dec 17;258:113731. doi: 10.1016/j.envpol.2019.113731. [Epub ahead of print] PubMed PMID: 31874442.

Wang X, Chang L, Zhao T, Liu L, Zhang M, Li C, Xie F, Jiang J, Zhu W. Metabolic switch in energy metabolism mediates the sublethal effects induced by glyphosatebased herbicide on tadpoles of a farmland frog Microhyla fissipes. Ecotoxicology and environmental safety $2019 \operatorname{Dec} 30 ; 186: 109794$. doi:

10.1016/j.ecoenv.2019.109794

Ward MH, Kilfoy BA, Weyer PJ, Anderson KE, Folsom AR, Cerhan JR. Nitrate intake and the risk of thyroid cancer and thyroid disease. Epidemiology. 2010 May;21(3):389-95. doi: 10.1097/EDE.0b013e3181d6201d. PubMed PMID: 20335813; PubMed Central PMCID: PMC2879161.

Wetzel DM, Kelley DB. Androgen and gonadotropin effects on male mate calls in South African clawed frogs, Xenopus laevis. Horm Behav. 1983 Dec;17(4):388-404. PubMed PMID: 6662518.

Williams BK, Semlitsch RD. Larval responses of three midwestern anurans to chronic, low-dose exposures of four herbicides. Arch Environ Contam Toxicol. 2010 Apr;58(3):819-27. doi: 10.1007/s00244-009-9390-z. Epub 2009 Sep 19. PubMed PMID: 19768486

Wolmarans NJ, Du Preez LH, Yohannes YB, Ikenaka Y, Ishizuka M, Smit NJ, Wepener $V$. Linking organochlorine exposure to biomarker response patterns in Anurans: a case study of Müller's clawed frog (Xenopus muelleri) from a tropical malaria vector control region. Ecotoxicology. 2018 Nov;27(9):1203-1216. doi: 10.1007/s10646-018-1972-y. Epub 2018 Sep 1. PubMed PMID: 30173332.

Wyngaarden JB, Stanbury JB, Rapp B. The effects of iodine, perchlorate, thiocyanate, and nitrate administration upon the iodide concentrating mechanism of the rat thyroid. Endocrinology. 1953 May;52(5):568-74. doi: 10.1210/endo-52-5-568. PubMed PMID: 13060263. 
Xie L, Zhang Y, Qu Y, Chai L, Li X, Wang H. Effects of nitrate on development and thyroid hormone signaling pathway during Bufo gargarizans embryogenesis. Chemosphere. 2019 Nov;235:227-238. doi: 10.1016/j.chemosphere.2019.06.177. Epub 2019 Jun 24. PubMed PMID: 31260863.

Xu P, Huang L. Effects of alpha-cypermethrin enantiomers on the growth, biochemical parameters and bioaccumulation in Rana nigromaculata tadpoles of the anuran amphibians. Ecotoxicology and environmental safety 2017 May; 139:431-438. Doi: 10.1016/j.ecoenv.2017.02.015

Xu Q, Oldham RS. Lethal and Sublethal Effects of Nitrogen Fertilizer Ammonium Nitrate on Common Toad (Bufo bufo) Tadpoles. Arch Environ Contam Toxicol. 1997 Apr;32(3):298-303. doi: 10.1007/s002449900188. PubMed PMID: 9096079.

Yang H, Liu R, Liang Z, Zheng R, Yang Y, Chai L, Wang H. Chronic effects of lead on metamorphosis, development of thyroid gland, and skeletal ossification in Bufo gargarizans. Chemosphere. $2019 \mathrm{Dec} ; 236: 124251$. doi: 10.1016/j.chemosphere.2019.06.221. Epub 2019 Jun 29. PubMed PMID: 31310984.

Yang M, Hu J, Li S, Ma Y, Gui W, Zhu G. Thyroid endocrine disruption of acetochlor on zebrafish (Danio rerio) larvae. J Appl Toxicol. 2016 Jun;36(6):844-52. doi: 10.1002/jat.3230. Epub 2015 Sep 23. PubMed PMID: 26397822.

Yaoita Y, Brown DD. A correlation of thyroid hormone receptor gene expression with amphibian metamorphosis. Genes Dev. 1990 Nov;4(11):1917-24. PubMed PMID: 2276625.

Yu NW, Hsu CY, Ku HH, Chang LT, Liu HW. Gonadal differentiation and secretions of estradiol and testosterone of the ovaries of Rana catesbeiana tadpoles treated with 4-hydroxyandrostenedione. J Exp Zool. 1993 Mar 1;265(3):252-7. doi:

10.1002/jez.1402650307. PubMed PMID: 8436918.

Zaya RM, Amini Z, Whitaker AS, Ide CF. Exposure to atrazine affects the expression of key genes in metabolic pathways integral to energy homeostasis in Xenopus laevis tadpoles. Aquat Toxicol. 2011 Aug;104(3-4):254-62. doi: 10.1016/j.aquatox.2011.04.022. Epub 2011 May 6. PubMed PMID: 21632027.

Zaya RM, Amini Z, Whitaker AS, Kohler SL, Ide CF. Atrazine exposure affects growth, body condition and liver health in Xenopus laevis tadpoles. Aquat Toxicol. 2011 Aug;104(3-4):243-53. doi: 10.1016/j.aquatox.2011.04.021. Epub 2011 May 6. PubMed PMID: 21635867

Zhang S, Zhang S, Zhu D, Jiao Z, Zhao X, Sun M, Che Y, Feng X. Effects of $17 \beta$ trenbolone exposure on sex hormone synthesis and social behaviours in adolescent mice. Chemosphere. 2019b Dec 16;245:125679. doi:

10.1016/j.chemosphere.2019.125679. [Epub ahead of print] PubMed PMID: 31869672.

Zhang W, Chen L, Xu Y, Deng Y, Zhang L, Qin Y, Wang Z, Liu R, Zhou Z, Diao J. Amphibian (Rana nigromaculata) exposed to cyproconazole: Changes in growth index, behavioral endpoints, antioxidant biomarkers, thyroid and gonad development. Aquat Toxicol. 2019a Mar;208:62-70. doi: 10.1016/j.aquatox.2018.12.015. Epub 2019 Jan 3. PubMed PMID: 30639745.

Zhang W, Deng Y, Chen L, Zhang L, Wang Z, Liu R, Diao J, Zhou Z. Effect of triadimefon and its metabolite on adult amphibians Xenopus laevis. Chemosphere. 
2020 Nov 3;243:125288. doi: 10.1016/j.chemosphere.2019.125288. [Epub ahead of print] PubMed PMID: 31743868.

Zhang Z, Le Velly M, Rhind SM, Kyle CE, Hough RL, Duff El, McKenzie C. A study on temporal trends and estimates of fate of Bisphenol $A$ in agricultural soils after sewage sludge amendment. Sci Total Environ. 2015 May 15;515-516:1-11. doi: 10.1016/j.scitotenv.2015.01.053. Epub 2015 Feb 14. PubMed PMID: 25682473.

Zhu L, Li W, Zha J, Wang M, Yuan L, Wang Z. Butachlor causes disruption of HPG and HPT axes in adult female rare minnow (Gobiocypris rarus). Chem Biol Interact. 2014 Sep 25;221:119-26. doi: 10.1016/j.cbi.2014.07.016. Epub 2014 Aug 7. PubMed PMID: 25108122. 


\begin{tabular}{|c|c|c|c|c|}
\hline Chemical & Species & Exposure & Effects & Reference \\
\hline \multicolumn{5}{|l|}{ Fungicides } \\
\hline Triphenyltin & L. sylvaticus & $\begin{array}{l}100 \text { days at } \\
0.1-1 \mu \mathrm{g} / \mathrm{L}\end{array}$ & Upregulated lipid metabolism. & $\begin{array}{l}\text { Higley et al., } \\
2013\end{array}$ \\
\hline Triclosan & S. tropicalis & $\begin{array}{l}1 \mathrm{yr} \text { at } 200 \\
\mathrm{ng} / \mathrm{L}\end{array}$ & Disrupted energy metabolism. & $\begin{array}{l}\text { Regnault et } \\
\text { al., } 2018\end{array}$ \\
\hline Triadimefon & $\begin{array}{l}P . \\
\text { nigromaculatus }\end{array}$ & $\begin{array}{l}28 \text { days at } 26 \\
\mathrm{mg} / \mathrm{L}\end{array}$ & $\begin{array}{l}\text { Reduced metamorphic rate. } \\
\text { Upregulated tsh } \beta \text {, dio } 2, \operatorname{tr} \beta \text {, dio } 2 \text {, } \\
\text { matrix metalloproteinase } 2 \text {, } \\
\text { TH/bZIP, and sonic hedgehog. }\end{array}$ & $\begin{array}{l}\text { Zhang W et } \\
\text { al., } 2018\end{array}$ \\
\hline Vinclozolin & $X$. laevis & $\begin{array}{l}4 \text { days at } 28.6 \\
\mathrm{ng} / \mathrm{L}-286 \\
\mu \mathrm{g} / \mathrm{L}\end{array}$ & $\begin{array}{l}\text { Reduced advertisement calling. } \\
\text { Increased rasping (unreceptive } \\
\text { call). Altered acoustic properties. }\end{array}$ & $\begin{array}{l}\text { Hoffmann \& } \\
\text { Kloas, } 2010\end{array}$ \\
\hline \multicolumn{5}{|l|}{ Herbicides } \\
\hline & $X$. laevis & $\begin{array}{l}\text { NF } 47-62 \text { at } \\
400 \mu \mathrm{g} / \mathrm{L}\end{array}$ & Disrupted energy metabolism. & $\begin{array}{l}\text { Zaya et al., } \\
2011\end{array}$ \\
\hline & L. pipiens & $\begin{array}{l}\text { GS } 25-42 \text { at } \\
1.6-3.7 \mu \mathrm{g} / \mathrm{L}\end{array}$ & $\begin{array}{l}\text { Downregulated dio3. Reduced } \\
\text { metamorphic success. }\end{array}$ & $\begin{array}{l}\text { Langlois et } \\
\text { al., } 2010\end{array}$ \\
\hline \multirow[t]{2}{*}{ Atrazine } & L. pipiens & $\begin{array}{l}\text { GS } 27-42 \text { at } \\
1.6-3.7 \mu \mathrm{g} / \mathrm{L}\end{array}$ & Female-biased sex ratio. & $\begin{array}{l}\text { Langlois et } \\
\text { al., } 2010\end{array}$ \\
\hline & L. pipiens & $\begin{array}{l}\text { GS 23- } \\
\text { metamorphic } \\
\text { climax at } 0.1- \\
25 \mathrm{ppb}\end{array}$ & $\begin{array}{l}\text { Female-biased sex ratio, gonadal } \\
\text { dysgenesis. }\end{array}$ & $\begin{array}{l}\text { Hayes et al., } \\
2003\end{array}$ \\
\hline $\begin{array}{l}\text { Glyphosate- } \\
\text { based } \\
\text { (VisionMax®) }\end{array}$ & L. sylvaticus & $\begin{array}{l}\text { GS } 25-42 \text { at } \\
2.9 \mathrm{mg} \text { a.e./L }\end{array}$ & $\begin{array}{l}\text { Reduced metamorphic rate. } \\
\text { Downregulated dio2. Upregulated } \\
\operatorname{tr} \beta \text { dio2, dio3, } \operatorname{tr} \beta \text {, and grll. }\end{array}$ & $\begin{array}{l}\text { Navarro- } \\
\text { Martín et al., } \\
2014\end{array}$ \\
\hline $\begin{array}{l}\text { Glyphosate- } \\
\text { based } \\
\text { (WeatherMax®) }\end{array}$ & L. sylvaticus & $\begin{array}{l}\text { GS } 6-37 \text { at } \\
2.9 \mathrm{mg} \text { a.e./L }\end{array}$ & Downregulated $\operatorname{tr} \beta$. & $\begin{array}{l}\text { Lanctot et al., } \\
2013\end{array}$ \\
\hline Linuron & S. tropicalis, & $\begin{array}{l}\text { Embryo to NF } \\
\text { stage } 40 \text { at } 9 \\
\mu \mathrm{g} / \mathrm{L}\end{array}$ & Female-biased sex ratio. & $\begin{array}{l}\text { Orton et al., } \\
2018\end{array}$ \\
\hline
\end{tabular}




\section{Fertilizers and Metals}

\begin{tabular}{|c|c|c|c|c|}
\hline Nitrate & B. gargarizans & $\begin{array}{l}\text { GS } 26- \\
\text { metamorphic } \\
\text { climax at } 100 \\
\mathrm{mg} / \mathrm{L}\end{array}$ & $\begin{array}{l}\text { Reduced metamorphic rate. } \\
\text { Partial colloid depletion. } \\
\text { Reduced T3 and T4 levels. } \\
\text { Downregulated dio2. } \\
\text { Upregulated dio3. }\end{array}$ & $\begin{array}{l}\text { Wang et al., } \\
2015\end{array}$ \\
\hline Lead & B. gargarizans & $\begin{array}{l}\text { GS } 26-42 \text { at } \\
50-1000 \\
\mu \mathrm{g} / \mathrm{L}\end{array}$ & $\begin{array}{l}\text { Follicular hyperplasia and colloid } \\
\text { depletion. } \\
50 \mu \mathrm{g} / \mathrm{L} \text { : Increased metamorphic } \\
\text { rate. Upregulated dio2, tra, and tr } \beta \text {. } \\
\text { Downregulated dio3. } \\
1000 \mu \mathrm{g} / \mathrm{L} \text { : Decreased } \\
\text { metamorphic rate. Downregulated } \\
\downarrow \text { dio2, tra and tr } \beta \text {. Upregulated } \\
\text { dio3. }\end{array}$ & $\begin{array}{l}\text { Yang et al., } \\
2019\end{array}$ \\
\hline
\end{tabular}

\section{Other pesticides}

\begin{tabular}{lllll} 
Azocyclotin & $X$ laevis & $\begin{array}{l}\text { Reduced metamorphic rate and T3 } \\
\text { 21 d at 0.1- } \\
0.5 \mu \mathrm{g} / \mathrm{L}\end{array}$ & $\begin{array}{l}\text { level. } \\
\text { Downregulated dio2, tr } \beta \text {, bteb, } \\
\text { matrix metalloproteinase 2, } \\
\text { stromelysin-3. }\end{array}$ & Li et al., 2016 \\
$\begin{array}{l}\text { DDE } \\
\text { (metabolite of } \\
\text { DDT) }\end{array}$ & $X$. laevis & $\begin{array}{l}\text { 4 days at } \\
3.18-318 \mathrm{ng} / \mathrm{L}\end{array}$ & $\begin{array}{l}\text { Reduced advertisement calling, } \\
\text { increased rasping (unreceptive } \\
\text { call). }\end{array}$ & $\begin{array}{l}\text { Hoffmann \& } \\
\text { Kloas, 2016 }\end{array}$ \\
\hline
\end{tabular}




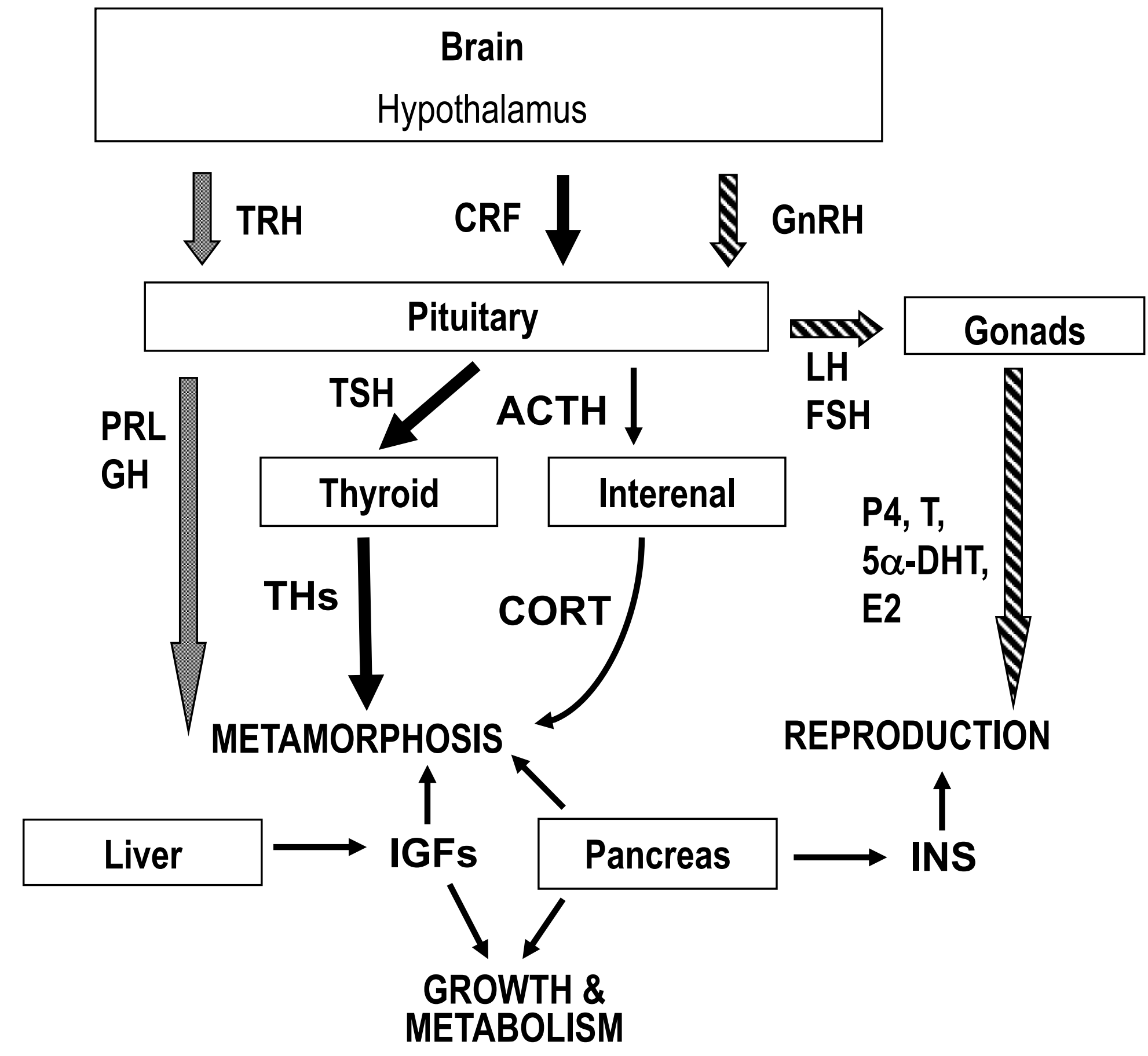

